\title{
Anmeldelser
}

\section{Danmarks kirker}

Udgivet af Nationalmuseet. SØNDERJYLLAND ved Erik Moltke, EIna Møller og Vibeke Michelsen. XXIII Sønderborg amt. 1961. $568 \mathrm{s.}$ — Tilføjelser og rettelser. Kunsthistorisk oversigt. Registre. $1963.482 \mathrm{s.}$

Med ikke mindre end 3092 sider er gigantværket om Sønderjyllands kirker nået $\mathrm{i}$ mål. Mon ikke det er det største værk om landsdelens kulturhistorie overhovedet? De tre foregående bind om kirkerne i Haderslev, Tønder og Åbenrå amter er omtalt i Sønderjyske Arbøger 1957288 ff, 1959183 ff og 1961254 f.

Bindet om Sønderborg amts kirker indeholder beskrivelse af 18 middelalderlige landsbykirker (herunder medregnet Nordborg), samt Mariekirken i Sønderborg, slotskirken sammesteds og Augustenborg slotskirke, hvortil kommer de kortfattede omtaler af nedlagte og nye kapeller og kirker. I forhold til Ảbenrå-bindet, der er på 384 s. og omfatter et tilsvarende antal kirker og kapeller, er fremstillingen taget kendeligt til i bredde. Kirkerne i Sønderborg optager mere end dobbelt så megen plads som de tilsvarende i Åbenrå, og på landsbykirkerne på Als er der ofret over 100 sider mere end på de tilsvarende i Ảbenrå amt. Heraf lader sig ikke slutte, at redaktionen har skiftet stil og er blevet mere snakkesalig. Med beundringsværdig fasthed bibeholdes de én gang vedtagne strukturprincipper (på godt og ondt), men om Sønderborg-kirkerne må der simpelthen være mere at fortælle, overleveringen må være betydeligere. Et væsentligt og særpræget element i Sønderborg-bindet er de kirker og kapeller, der har haft tilknytning til hertug Hans og hans slægt. Her bør fremhæves, at redaktionen af afsnittet om Sønderborg slotskapel er foreståt af vor fine kender af Sønderborg slot, dr. Otto Norn. Men også områdets tilknytning til skelsættende begivenheder i rigets historie (Dybbøl etc.) har sat sine spor i kirkernes beskrivelse, så dette bind herved kan påregne en bredere interesse end de andre tre.

Den kunsthistoriske oversigt overflødiggør begribeligvis de sammenfatninger, som forsøgtes $i$ anmeldelserne af de tidligere bind, og de bemærkninger, der her skal gøres, må koncentreres om dette med så megen spænding imødesete arbejde.

Værket om de sønderjyske kirker omhandler i kraft af fællestitlen DANMARKS KIRKER kun de 8 købstads- og flækkekirker 
og de ca. 170 kirkebygninger og stiftelser, som befinder og befandt sig i de henved 120 middelalderlige sogne, der ligger inden for nuværende dansk rigsområde. Det siger sig selv, at en syntese på dette grundlag ikke er mulig, al den stund grænsedragningen i 1920 skilte et kulturhistorisk set homogent område. Et brugeligt supplement for de sydslesvigske foreligger ganske vist $i$ det sydfor grænsen udgivne inventarværk Kunst- und Baudenkmäler Schleswig-Holsteins, påbegyndt med Tønder- og Husum-bindene 1939. Men det ville være ønskeligt, om kommende værker af denne art kunne udgives som fælles dansk-tyske publikationer, for værket om Sønderjyllands kirker ville have været fuldkomnere, om hele det gamle hertugdømme havde været behandlet under ét, og med en samtidig tysk version ville det kunne anvendes af en langt større kreds. Et standardarbejde som dette har samme værdi for dansk og tysk forskning.

Den kunsthistoriske oversigt på nær 300 sider omfatler kapitlerne arkitektur, glasmalerier, kalkmalerier, sten- og billedhuggerarbejder, træskærerarbejder, tavlemaleri, portrætter og staffering, samt metalarbejder. Hver for sig udgør disse sammenfatninger fortættede materialesamlinger til brug for kommende specialfremstillinger, og de gør det uendelig meget lettere for fremtidige kunst- og kulturforskere at gå i gang med det væld af uløste problemer vore gamle kirker rummer.

Mest omfattende er afsnittene om arkitektur og træskærerarbejder, de udgør to tredjedele af hele oversigten. Det fortræffelige materialekort, ved hjælp af hvilket samtlige kirkers byggematerialer og kronologi i grove træk er anskueliggjort, burde udgives som skolekort. Det illustrerer også den tredeling i det sønderjyske kirkebyggeri, som er Elna Møllers konklusion: 1) Den nordøstlige del (dele af Haderslev og Ảbenrå amter) med granitkvadre og overensstemmelse med nørrejyske traditioner, 2) vestlandet med tuf-tegl-granit-kirker og en via Ribe og Nordsøen modtaget kontinental arkitekturtradition og 3) ostlandet med kampestenskirker og slægskabsforhold til Fyn med Østersø-sejladsen som forudsætning. Men understreget bliver det samtidig, at selv de områder, hvor fremmede impulser er lettest at påvise, udvikler en milieubestemt stil fra første færd.

Den samme lokalprægede tendens fastslås (med Mackeprang) for de mange middelalderlige døbefontes vedkommende. De 109 middelalderlige og 37 eftermiddelalderlige er et imponerende materiale, men redaktionen lægger her en beundringsværdig forsigtighed for dagen over for fristende værkstedssammenstillinger, det samme også i det spændende kapitel om træskærerarbejderne, oversigtens ubestridte hovedbedrift. I en omfangsrig indledning gennemgås principperne for bestemmelse af kronologi, proveniens og værksted, en kunsthistorisk metodik, som enhver kunst- og 
historiestuderende skulle tvangsindlægges med! Det påpeges, hvilken jungle man befinder sig $\mathrm{i}$, når (specielt de middelalderlige) træskulpturer skal bestemmes, og der ironiseres veloplagt over tidligere konklusioner.

Sønderjyllands rolle som brydningsfelt for nordisk og ovrig europæisk kultur viser sig med tydelighed i den problematik, der knytter sig til den middelalderlige skulpturs herkomst. Mod teorien om et specielt lybsk supremati står den, der fremhæver en lokal, til dels fransk påvirket tradition, og redaktionen (Moltke) bevæger sig formelig på kattepoter i dette vildnis, men dog med overvejende skepsis over for Lübeck-tilhængerne.

Materialet i Sønderjylland er det rigeste i Danmark. Billedstormen var ikke så voldsom her, hvor reformationen tog sin begyndelse, og den for landsdelen karakteristiske konservatisme har sidenhen på sælsom vis hindret større omvæltninger. Hertil kommer den af redaktionen smukt fremhævede redningsaktion fra Richard Harpt, hvem vi skylder, at kirkeinventar, deponeret i Flensborg museum, efter Genforeningen kunne føres tilbage til de kirker, fra hvis lofter Haupt havde reddet det for ødelæggelse (i øvrigt med en problematik, som kan minde lidt om de islandske håndskrifter), men - som tilfældet også er det med det profane kunsthåndværk - gælder dette kun for landsbykirkerne. Købstadskirkerne, som selvfølgelig har haft de værdifuldeste skulpturer, var ribbede, før museumsvæsenet kom ind i billedet.

Spørgsmålet om, hvorfra unggotikkens (senromanske) arbejder, stammer: direkte import, importerede værksteder eller rent sønderjyske, besvarer Moltke med det forsigtige: Det kan ikke afgøres. Man må vel håbe med et underforstået endnu. For hvad er der ellers tilbage for den fremtidige forskning? Bemærkes skal dog, at naturen $\mathbf{k}$ a n gå over optugtelse, men hvem kan bebrejde vor elskelige runolog, at tilstedeværelsen af runer på Hüruppassionens figurer og rammeværk virker på ham som trompeter på dragonheste? Altså: o. 1250 har der været $i$ alt fald eet dansk værksted i Sønderjylland!

Det er spændende læsning dette her. Detektivarbejde, som anmelderen som lægmand kun kan imponeres over, men som det vil kræve et liv blandt helgener at behandle i detaljer. Fra den meget anonyme højgotik med vor ældste stående Madonnafigur (Bjerning) og til sengotikken med dens skarpsindigt påpegede sgrupper* (ikke værksteder) kommer vi ind i den sækulariserede og kedelige renæssance med masser af navne og sikre værksteder. Undervejs nedlægges alskens vildt, også dem, der har taget Imperialissima-mesterens navn forfængeligt. Kun Rabsteds altertavle tør placeres i dette værksted, mens Abilds og Logumklosters er gjort andetsteds. En fejl $\mathbf{i}$ anmeldelsen af Tonder-bindet (Sdj. Arb. 1959, s. 184) korrigeres hermed skyldigst! 
I det onfattende afsnit vedrørende renæssancens overvejende prædikestole og epitafier må særlig fremhæves det store kritiske afsnit om Hinrich Ringerinck, som damer et fornemt grundlag for en længe savnet monografi over denne interessante Flensborghilledskærer.

Også afsnittet om tavlemaleri, portrætler og staffering er Moltkes (med undtagelse af en analyse af Logumklosters antemensale). Mange store navne moder os her, men kvaliteten imponerer ikke. Skade, at vi i Tonder må afskrive Jürgen Owens, men vi får vel troste os med, at andre har mistet mere, efter at trekloveret $i$ Prinsens Pala besteg buldozeren.

Af de af Vibeke Michelsen redigerede afsnit skal blot fremhæes af snitlet on guldsmedearbejderne, ikke fordi de svrige ikke fortjener det, men fordi nelop dette illustrerer kirkevaerkets store videnskabelige værdi. Det sonderjyske kirkesølv er i modsæetning til træskærerarbejderne af relativ sen oprindelse, d. v. s. fortrinsvis ef ter 1600, men vor viden om guldsmedekunst $i$ det hele laget er meget beskeden, sà hvad det er lykkedes at nå frem til her, specielt for senrenassancens og barolkens vedkommende, er overraskende fuldslandigt. 'Takket være Sønderjyllands Kirker er vor landsdel den bedst belyste $i$ hele landet $\mathrm{m}$. h. t. mestre og mestermærker ijvf. Marie Louise Jorgensens righoldige guldsmedefortegnelse).

Det er uundgâeligt $\mathrm{i}$ et vark af denne dimension, at det vrimler " med fejl (som diskret indsendes til redaktionen!), men de er ganske uvasentlige $\mathbf{i}$ forhold til de værdier, vi har fảet $\mathbf{i}$ hænde.

I den mere festlige middelalder havde kirkeklokkerne ringet $i$ Sonderjylland den dag, det sidste hafte udkom. Rungende tedeummer havde lydt til pris af treenigheden fra Frederiksholms Lanal. Og mon ikke man i Lübeck havde igangsat en seriefremstilling af S. Elna selvtredje med S. Erik pá sin højre og S. Vibs pâ venstre arm? Nej, undskyld, hos den danske runemester i Flensborg.

Vi hernede (og specielt fra Historisk Samfund for Sonderjylland) ma i en mere nogtern tidsalder begrænse hyldesten til en varm tak for en flot bedrift og for de incitamenter, kirkeværkets muntre redaktorer bragte landsdelen, mens de arbejdede her. Forlaxngst har de släet lellet op andre steder. Men selv om de ikke kan udfore fornemmere arbejde i de mange resterende amter, under vi ogsa disse dell glade, vi h a r haft.

Sigurd Schoubye. 
Holger Hjelholt: Christian Hansen junior (1804-1873). En talsmand for flensborgsk kongetroskab

Gyldendal 1963, $116 \mathrm{~s}$.

"Jernbane-Hansen " kaldtes den driftige flensborger, som dr. phil. Holger Hjelholt har skildret i ovennævnte skrift. Det var med god grund, flensborgerne havde givet den iøvrigt afholdte og respekterede mand dette ogenavn. Jernbanen, d. v. s. tværbanen fra Flensborg til Husum og Tonning, var den idé, Christian Hansen jun. utrættelig brod en lanse for lige fra slutningen af 1830'erne - kun 6-7 år efter den forste engelske jernbanelinies âbning - til 1854, da tværbanen omsider blev taget $\mathrm{i}$ brug.

Hans grundtanke var den, at en sâdan tværforbindelse gennem Slesvig ville dæmme op for den overmægtige hamborgske indflydelse og skaffe Danmark en eksporthavn mod vest. Det var en reaktion mod tanken om en jernbane fra Hamborg eller Altona til Kiel. Hansens meningsfalle, den flensborgske politiker og sukkerfabrikant Peter Nielsen, rammer godt nok hans stemmeføring, når han over for Frederik VI udtaler, at den holstenske tværforbindelse ville vare »det samme, som at afhugge Danmarks hoved og lade blodet flyde i Elben«. Bag disse tanker gemte der sig en rigelig portion lokalpatriotisme og flensborgske forretningsinteresser, rettet specielt mod den overlegne konkurrent Hamborg, hvis lkredit man dog ikke kunne undvære. Hansens forestillinger om tværbanens virkninger pá handelslivet $i$ de tre nævnte slesvigske byer bærer unægteligt et fantastisk præg, nâr Elbstadens kapitaloverlegenhed tages i betragtning. Men i ovrigt var den slesvigske tvarbane et rimeligt projekt. Dette bevises af, at det var engelsk kapital, der omsider fik banen fuldført, ganske vist samtidig med en forbindelse fra Øster Ørsted til Rendsborg, hvorved tværbanen blev tilsluttet det holstenske jernbanenet. Hamborgs overvægt formảede tværbanen ikke at bryde. Den direkte Englandsforbindelse blev noget af en skuffelse.

Jernbanesagen og Christian Hansens velmente, men omstandelige pjecer og artikler om denne, optager en sådan plads i mandens liv, at det er nær ved at blive for meget for Holger Hjelholt, der etsteds føler sig fristet til at bifalde begyndelsen til en af Hansens pjecer: $\gg \mathrm{Ak}$, Gud, atter jernbanen!" Han tager sig dog i det og fortsatter: "Men da Christian IIansen var utrættelig $i$ at fore pennen til kamp for sin jernbaneidé, er det ikke passende, at vi Irætles". Argumentet er ikke helt overbevisende, og en og anden læser ville vel have foretrukket kortere referater af Hansens skrifter mod til gengæld at fâ en bedommelse af de konkurrerende projekter ud fra nationalokonomiske eller samfærdselstekniske synspunkter, men det má indrømmes, at dette let ville kunne sprange en levnedsskildrings ramme. 
Christian Hansens liv (og herunder hans kamp for tværbanen) vækker imidlertid læserens umiddelbare sympati. Født uden for ægteskab af en tjenestepige i nærheden af Ribe gennemlever han en forældreløs barndom, som kun er rig på afsavn og slid. Han arbejder sig op, kommer til Flensborg og opnår i 1846 ansættelse som havne- eller broskriver. Senere udnæunes han til kontrollor ved den slesvigske centralkasse, men må i 1864 forlade Flensborg; han bliver da knyttet til Assistenshuset i Kobellhavn, fra 1867 som forvalter, en velfortjent belønning til en mand, der utrættelig havde slået til lyd for bevarelsen af Flensborgs forbindelse med moderlandet.

Med kyndighed har dr. Hjelholt sat den biografiske skildring ind $i$ tidens ramme. Man kunne have onsket en skarpere analyse af Christian Hansens »flensborgske kongetroskab", så dens sammenfiltring med økonomiske og lokalpatriotiske synsmåder var trådt klarere frem. Men ogsä uden dette giver det lille skrift et levende indtryk af en stræbsom, men tiltalende flensborger, der med en stundom trættende ihærdighed kæmpede for sine ideer ud af et bravt patriotisk sind.

Lorenz Rerup.

\section{H. P. Sørensen: Træk af Gram Sogns Historie}

Eget forlag. 1963. $474 \mathrm{~s}$., ill.

Forfatteren der i mange år var lærer i Gram, har efter adskillige års forberedelse kunnet udsende en smuk og veludstyret bog om Gram sogns historie. Den beskedne titel, som bogen bærer, burde måske findes ved enhver sognehistorie. Et sogn er en lille verden, hvori en stor del af den store verdens begivenheder afspejler sig, og at bringe sognets lange historie $i$ et enkelt bind kan derfor kun lade sig gore ved en kraftig sortering af stoffet. Det kan så altid diskuteres, om det rigtige er kommet med.

Bogen er $\mathrm{i}$ hovedsagen kronologisk bygget op, men forfatteren fár dog $\mathrm{i}$ et indledende kapitel lejlighed til at præsentere sognet med en del af dets markante træk, slottet, en del virksomheder og institulioner, landsbyer og personer.

Det må hilses med glaede, at afsnittet om oldtiden er så langt som det er, hele 19 sider. Der er ikke mange sognehistorier, hvor delte længste og meget vigtige afsnit af historien får så god mulighed for at gøre sig gældende, som i det velskrevne afsnit, der her bringes. Det kniber jo altid med at finde lokalt stof til middelalderens historie, og netop derfor er det vigtigt, at oldtidens historie får lov til at give livet i landsbyen perspektiv.

De folgende afsnit, om slottet og dets ejere, landbruget, arbejde og fest i det 19. i̊rh., fattigvæsen og kriminelle sager, behandler den del af historien, hvor arkivmaterialet spiller den storste rolle. 
Det må her siges, at disse afsnit indeholder for mange dokumenter, der gengives i deres fulde ordlyd. Et sådant dokument har ganske vist sin egen værdi. Selv i den trykte form har det nogel af museumsgenstandens tilforladelighed over sig, og i en populær bog skal det ikke anbringes bag $\mathrm{i}$ bogen, men skal give selve teksten en tidskolorit, som referatet ikke kan have. Men der er afsnit i denne bog, hvor disse dokumenter næsten fortrænger forfatterens egen tekst, og hvor det må befrygtes, at en og anden læser falder fra.

Og det ville vare synd. For bâde slutningen af de her nævnte kapitler og ikke mindst i afsnittene om kirkeliv i Gram sogn og nationale brydninger 1830-1940 bliver fremstillingen igen flydende, letlæst og interessant ved selvstændige betraglninger og vurderinger og ikke mindst ved det af forfatteren indsamlede lalmateriale og traditionsslof fra nyere tid. Bogen er ført helt op til dato. Slottets historie slutter med et brudebillede fra 1963 af det unge grevepar, og af snittet om landbruget slutter med en indgående omtale af kotellet fra 1961. Af oplysninger fra nyeste tid er meget mere, end man skulle tro, gået tabt i løbet af kort tid, og derfor er disse afsnit med til at sikre denne hogs varige værdi. Den skal nok få læsere.

Hans Neumann.

\section{Sigurd Schoubye: Hollandske Vægfliser}

Thaning \& Appel. 1963. 112 s. 58 ill.

Dr. Sigurd Schoubye har udsendt en bog om de hollandske vægfliser, der ved siden af det sønderjyske sølv hører til hans yndlingsemner. Han har tidligere skrevet om samme emne i en publikation fra 'Tonder Museum (1949) og i et kapitel i Sv. Tito Achens fornøjelige "Jeg er samler" (II, 1956), og den nye bog slutter sig for så vidt til de foregående, hvad angår flisernes fremstilling og billedmotiver omend med tillæg af visse præciseringer af senere vundne resultater, også de seneste hollandske, næsten før end de er ført i pennen. Geografisk begrænser Schouhye sig til Vestslesvig, men er ganske klar over, at flisernes betydning, keramisk og handelspolitisk, for den dansk-norske kulturkreds senere mâ klarlægges som et ikke uvæsentligt led i den næsten verdensomfattende hollandske fliseeksports historie.

Men bogen er ikke blot skildring, den har også en thesis, en bestemt idé, som forfægtes med megen styrke. I korthed går den ud på, at fliserne først er hjemtaget til bøndergårdene, og at det forst er senere, da oboerne er kommet til større velstand, at de har vundel indpas i skippermilieuet. Endvidere at de ældste fliser er indkommet i studehandelens tid ca. 1550-1650 i den nordlige del af Slesvig, mens flisetraditionen $i$ den sydlige del er senere og knytter sig til hvalfangstperioden i $\mathbf{1 7 0 0 - a ̊ r e n e . ~ F o r ~ d e n ~ f o r s t e ~ p e - ~}$ 
riode regner Schoubye med Rotterdam som hovedleverandør, mens hovedparten af de yngre og langt talrigere anses for frisiske. Delft er $\mathrm{i}$ den forbindelse af mindre betydning; men det er svart al skelne mellem produkterne fra Utrecht, Amsterdam og Friesland, som har brugt de samme modelbøger. Uanset dette har Schoubye sikkert ret $i$, at de fleste sønderjyske fliser er af frisisk herkomst. Af de frisiske virksomheder lever 'Tichelaars fabrik i Makkum fra 1660 stadig i bedste velgående. Den er af væsentlig storre betydning, end dens sparsomme omtale i litteraturen lader ane. En del af de slesvigske fliser er kommet herfra; men Schoubye er ikke utilbøjelig til at mene, at Harlingen, hvis sidste værksted lukkede i 1933, i højere grad har forsynet Vestslesvig. Der er iøvrigt den mulighed, at den frisiske fliseproduktion er ældre end hidtil antaget, og den kan da true Rotterdam som før næunt hovedleverandør af de tidlige fliser, også de flerfarvede.

Oprindelig nojedes man med at beklæde vinduesveggene med fliser, men i 1700-årene kom man ind pá at dække flere eller alle fire vægge $i$ en stue, og da kunne der nok gâ 3-5000 fliser til. Lidı bittert slås det fast, at nu giver kun ganske få huse nogen fornemmelse af denne udsmykning. Som Schoubye rigtigt fremhæver, er fliserne stærke vidnesbyrd om forbindelsen med Holland. og der, hvor der er fliser, vil der som regel ogsâ være andet nederlandsk kulturgods. Men hollandsk indflydelse pâ nordisk hjemindretning, fliser, fajancer, ure og messingtøj er ik ke meget oplyst. I 1945 udkom et iøvrigt udmærket værk Holland-Danmark I-If, hvor man forgæves søger et stykke fajance eller en flise, som ellers er meget væsentlige vidnesbyrd om dansk-hollandske forbindelser.

I en bog om fliser er billedstoffet af meget stor betydning. Det er her fortrinsvis hentet fra Tønder Museums rige samlinger. Alle væsentlige flisetyper er gengivet, de polykrome endda i farver, hvad der er en stor fordel, men en sver kunst, og der er dertil interiører, der viser flisernes oprindelige placering og særlige massevirkning.

Schoubyes bog rummer en meget betydelig viden på de forholdsvis få sider. Mâske er den lidt snæver $\mathbf{i}$ anlægget, men ellers en kyndig, velskrevet og velillustreret bog om det interessante hjørne af den sønderjyske kultur, der hedder den hollandske vægflise i V'estslesvig.

Sigvard Skov. 
Johan Hvidtfeldt: Kampen om ophavelsen af livegenskabet i Slesvig og Holsten 1795-1805

Mit einer Zusammenfassung in deutscher Sprache.

Skrifter, udgivne af Historisk Samfund for Sønderjylland nr. 29-1963. 518 s. (Disputats.)

Livegenskabets ophævelse er en central begivenhed i hertugdømmernes historie. Reformen fik afgørende social, økonomisk og politisk betydning. Socialt hævede den en meget stor del af den slesvig-holstenske bondestand op fra trældom til menneskeværdig tilværelse, okonomisk var dens betydning gennemgribende for hertugdømmernes landbrug, og politisk satte den sig spor langt ind i fremtiden, idet den bl. a. blev et udgangspunkt for det holstenske ridderskabs had til alt, hvad der var dansk.

Emnet er behandlet for i den historiske litteratur, men særbehandlingerne er alle af ret gammel dato - hovedværket, indtil Hvidtfeldts bog forelå, var Georg Hanssens "Dic Aufhebung der Leibeigenschaft und die Umgestaltung der gutherrlich-bäuerlichen Verhältnisse überhaupt in den Herzogthümern Schleswig und Holstein " fra 1861 - og de nyere forskere, som $i$ anden forbindelse har strejfet emnet, har kun pletvis kastet nyt lys over problemerne.

Johan Hvidtfeldts værk, for hvilken han erhvervede den filosofiske doktorgrad ved Århus universitet, er blevet en stor bog. Emnet behandles på 433 sider, hvortil slutter sig noter, litteraturliste etc. samt et resumé på tysk. Der bygges på et meget stort kildemateriale fra arkiver i Tyskland og Danmark (Landesarchiv Schleswig-Holstein på Gottorp, statsarkiverne i Hannover og Oldenburg, Rigsarkivet i København, Landsarkivet i Âbenrå, en række godsarkiver i privat eje, byarkiver, manuskriptsamlinger i biblioteker m.v.). Alene den arbejdspræstation, der ligger bag bogen, aftvinger respekt.

Den afgørende kamp om livegenskabets ophævelse stod $i$ årene 1795-1805, men forinden var der sket meget, der fik betydning for denne kamp, og forfatteren giver sig tid til at skildre dette med grundighed. Først ridses det op, hvorledes livegenskabet opstod i senmiddelalderen, bl. a. som følge af alvorlige landbrugskriser, idet udviklingen dog langtfra var ens $i$ de tyske lande, og livegenskabet opstod til forskellig tid og under forskellige former. Tidspunktet for dets opståen i Slesvig-Holsten lader sig ikke fastslå med sikkerhed. Det synes ældst i Holsten, hvor der skete en udpræget forringelse af bondestandens stilling i 1400-årene. Vi finder det i nyere tid på alle godser i Holsten på nær marsk-godserne og ganske enkelte andre. I Slesvig, hvor det indfortes senere, blev det knapt så udbredt (men gik dog længere nordpå, end man tidli- 
gere har regnet med). Her var man fri for det på en del små godser, især dem, der ikke havde egen jurisdiktion, idet deres bønder var tingpligtige under amt og herred. De lå især $\mathrm{i}$ Tonder amt og i den vestlige del af Angel. Hertil kom de augustenborgske godser pả Als samt Lindeved gods i Flensborg amt. I de slesvigske amter var der ikke livegenskab; det samme gjaldt for en stor del af de holstenske amters vedkommende. Forfatteren fremhæver, hvor afgorende det var for livegenskabets indforelse i et område, om bøndergodset til en herregárd lâ saledes samlet, at godsejeren kunne skabe et birk, hvor han helt og holdent kunne gøre sig til retsherre. Hvor en sådan jurisdiktion kunne elableres, var der basis for livegenskab.

I løbet af 1700-årene bliver livegenskabet som så mange andre samfundsforhold sat under debat af en europæisk litteratur og mere eller mindre skarpt fordomt. Dels i forbindelse med den litterære debat, dels som resultat af praktiske overvejelser skete der hist og her rundt i Europa forbedringer af bondestandens stilling, herunder ophævelse af livegenskab. Det var sãledes bl.a. tilfældet i Østrig, hvor kejser Joseph 2 som den forste i Europa afskaffede det. Senere blev det afskaffet i Baden. Andre bondereformationer fandt sted i Preussen, og endelig fik de kongerigske danske landboreformer naturligvis deres ganske sarlige betydning for udviklingen i Slesvig og Holsten.

Allerede i 1600-årene var livegenskabet blevet ophævet pá enkelte godser i hertugdømmerne, hvad der dog nærmest mâ betragtes som en lokal kuriositet, men i lobet af 1700-tallet begyndte der så småt at komme en udvikling $i$ gang bade her og $i$ kongeriget. Samtidig med, at de kongerigske landboreformer gennemførtes i sidste halvdel af 1700-tallet, ophævedes livegenskabet pâ de slesvigske og holstenske domænegodser og pá enkelte private godser, ligesom der $\mathrm{i}$ det hele taget gjordes forskellige tillob til reformer. Når godsejerstanden i disse år nogenlunde villigt lånte øre til reformtanker, skyldes det bl. a., at højkonjunkturer gav landbruget stærkt forøgede indtjeningsmuligheder, og gennem reformer skulle det være muligt at opnå intensivere udnyttelse af jorden. Forfatteren gor grundigt rede for denne vigtige baggrund for reformerne, men lægger ogsâ megen vægt pâ de teoretiske og ideelle motiver bag reformgodsejernes indsats og gør omstændeligt rede for den litterære debat om spørgsmålene, især fremhæver han betydningen af de tanker, der fremførtes af de tyske kameralister, en slags praktisk filosofi, der pâ sin vis peger frem mod vor tids tanker om "velfardsstaten .

Den 16. januar 1795 blev en skæringsdato for hele udviklingen i denne sag. Den dag holdt de godsejere, der ikke hørte til ridderskabet (de ikke-reciperede) deres ârlige møde i Kiel. På dette møde stillede godsejer F. O. V. Lawätz forslag om, at de ikke- 
reciperede skulle træde sammen med ridderskabet og rádslá om, pá hvilken måde livegenskabet på den mest fordelaglige mâde kumne ophaves på alle godser inden et bestemt tidspunkt. Nu var der ikke noget særligt hjerteligt forhold mellem de ikke-reciperede og ridderskabet, og det - som det synes - noget formlost frem satte forslag var næppe tankt som nogen venlighed overfor ridderskabet. Det synes at vare blevet modtaget ret koligt i forsamlingen, men alligevel endte madet med, at der blev sendt ridderskabet en afskrift af protokollen desangående, og dermed var lavinen begyndt at rulle. Der kunne ganske vist ikke vare megen tvivl om, hvordan ridderskabets flertal sa pa sporgsmálet. Jet var imod så vidtgående reformer. Men i Ǩ̉benhavn sad kronprins Frederik og hans reformvenlige regering og spejdede efter et iniliativ fra hertugdømmerne, rede til at gribe ind og lagge pres pá ridderskahet. Hvidtfeldt stiller med rette det sporgsmál, om Lawätz kan have haft kontakter i Kobenhavn, men har ikke kunnet finde noget, der bekræfter dette.

Ridderskabets synspunkter vedrorende forslaget on livergenskabets ophrevelse kom til orde pá el mode den 8 . juli 179:5. Der blev i kønne ord givet udtryk for det principielt onskelige $i$, al bonderne blev frie, men der var stort set enighed om, at man ikke kunne tage nogen beslutning. der bandt alle godsejerne. Regeringen i København, og det ville i forsle rakke sige A. P. Berm. storff, pressede imidlertid pä, og i januar 1796 nedsalte ridderskabet en kommission, der skulle arbejde med sagen, i den indtrådte senere nedlemmer fra do ikke-reciperede godsejere. Om kommissionens droftelser, dens henvendelse til godsejerne og disses reaktioner fàr vi meget at vide. Reformmodslanderne i kommissionen var stærke, og reformvennerne kunne ikke enes om en politisk linie. Man afsluttede kommissionsarbejdet med en henvendelse til kongen, der gik ud pá. al man i det vapsentlige vall enige om, at det personlige livegenskab skulle afskalfes, og man var indstillet på, at det skete indenfor en 8-árs periode. De politiske forhold ude $i$ verden og hjemme i det dansk-tyske monarki var nu sâdan, at det lå klart, at her var ingen vej tillbage. Det ẹ egentlig ikke mere spørgsmålet om, hvorvidt livegenskaloet skal ophæves, kampen står om, men om på hvilken máde det skulle ske. Livegenskabet var en så integrerende del af de slesvigske og holstenske godsers forfatning, at sporgsmálet om linien og tempoet $\mathrm{i}$ reformen var livsvigtigt for landsdelens godsejere.

Hvidtfeldt forsøger at dele sol og vind lige. Han er klar over, at det er urigtigt at betragte reformvennerne blot som helte og modstanderne som de rene skurke. Han understreger, at modstandernes meninger godt kan have været bestemt af "en ærlig overbevisning om, at den vej, de vil gå, er den eneste rette, ikke blot for dem selv og deres stand. men også for staten, ja selv for 
undersállerne. Man má ikke glemme, at mange af dem i deres syn på bonderne er bundet af ärhundredgamle traditioner".

I Kobenhavn rykkede man skridt for skridt nærmere ind pâ livet af den endelige afgorelse. Men mange sporgsmanl målte klares i forbindelse med livegenskabets ophævelse. Der var sáledes hoveriproblemet. Hoveriet var så nær knyttet til livegenskabet, at det ikke kunne bestâ uden detle, men det ville vaere en alvorlig sag for godsernes fortsatte forsvarlige og rentable drift, om det uden videre ophævedes. Der var ogsâ spørgsmålet, om godsejerne skulle have adgang til at lagge jord fra hondermarkerne ind under lovedgardsjorden. Der var sporgsmál vedrorende de jordiose landarbejdere og tyende o. m. a., og ogsá landels forsvar berortes stærkt af reformerne. Det bliver da afgørende, at kronprins Frederik personlig sætter ind med stor styrke og får slâet fast, at bondestanden $\mathrm{i}$ hertugdommerne skal opretholdes og alt hoveri være fastsat. Hvidtfeldt mener iøvrigt, at kronprinsen her ræsonnerer ud fra en kameralistisk tankegang.

1) 19 . december 1804 kom forordningen om livegenskabels "phavelse i Slesvig og Holslen, en af de vighigste love, der nogensinde er udsledt for de to hertugdømmer. Reformarbejdet var allerede godt i gang mange steder, men nu kunne det fores til hunds.

Forordningen greb dyltt ind i herlugdommernes okonomiske liv, og et al de områder, hvor virkningerne var mest følelige, var vedrørende godsernes arbejdskraft. Tidligere havde man kunnet disponere over de hoveripligtige gârdes mandskab til arbejdet pä hovedgárden. Nu var man i det væsentlige henvist til at hjælpe sig med daglejere, og i foråret 1805 synes godsejerne at have næret alvorlig frygt for, at der ikke skulle kunne skaffes tilstrækkelig arbejdskraft til jordens pasning.

I deme situation indtraffer en ejendommelig episode. Glïckstadt-regeringen lod indskerpe, at kontrakter om hoveri, efter plakatens (mandatets) ordlyd også om ubestemt hoveri, skulle respekteres. Kironprinsen blev rasende, og man skyndte sig at forklare, at ordet "ubestemt "var en beklagelig trykfejl. Sagen blev berigtiget, og reglerne om kontrakter mellem godsejere og bønder, herunder også kontrakter, der rummede hoveriaftaler, blev yderligere udformet. Fpisoden viser, hvor personlig engageret kronprins Frederik var i hele denne sag, og hvad dette betød for, at reformen blev gennemført til bunds. Hvidtfeldt lader da ogsâ sin bog munde ud $i$ en hyldest til ham og hans indsats.

Med „Kampen om ophævelsen af livegenskabet i Slesvig og Holsten 1795-1805 " er ikke blot hertugdømmernes historie, men vesteuropæisk landbrugshistorie blevet beriget med et stort og værdifuldt værk. Forfatterens kendskab til kildematerialet er dybtgäende, hans viden om tids- og stedforhold og de agerende 
personer er overordentlig stor. Hans omstændelighed ved gennemgangen af synspunkter og debatter er ganske vist nu og da noget belastende for værkets overskuelighed, og i samme retning virker hans trang til - mere og mindre grundigt - at behandle de sideproblemer, der knytter sig til hovedproblemet, men det må retfærdigvis indrømmes, at spørgsmålet om livegenskabets beståen eller ikke-beståen greb ind på så overordentlig mange omrâder, okonomiske, sociale, militære o.s. v., at undersøgelser ogsả af dem trænger sig på.

I fremstillingen har forfatteren sogt at fremme klarheden ved stærk opdeling i underkapitler, noget læseren i høj grad pâskønner. Hans bedømmelse af dramaets hovedpersoner er sober. Sympatien for reformernes forkæmpere er umiskendelig, men modstanderne behandles med respekt og forståelse, og skildringerne af dem er i virkeligheden ofte de dygtigst gjorte.

Sigurd Jensen.

\section{Peder H. Smidt: Hverdag og Fest}

Udgivet af Historisk Samfund for Sønderjylland 1964. 155 s., ill.

Denne erindringsbog er med rette blevet imodeset med forventning. Man vidste, at Peder $H$. Smidt pâ Spandetgård var en pennens mand, og vi ved nu, at han som ung havde kunnet tanke sig at gå i pressens tjeneste, hvad den sonderjyske presse sikkert også ville have været godt tjent med. Præslefolkene i Spandet, pastor Wilhelm von Brincken og frue, havde, oplyser han, tilbudt at ville bekoste hans uddannelse med en gerning i Sonderjylland for øje, men skønt han ikke havde særlig lyst til at blive landmand, blev det dog den vej, han gik. Det var hensynet til forældrene, der var optanter, og som derfor kunne risikere en udvisning, som blev afgørende for ham. Lysten til at betro sig til papiret gik dog ikke tabt. Han har gennem årene $i$ en lang række artikler, som regel $\mathrm{i}$ "Hejmdal ", givet udtryk for sine meninger og synspunkter vedrørende nationale og kirkelige sporgsmål.

Denne bogs værdi består $i$, at den er skrevet af en mand, der har levet med i alle begivenheder og omskiftelser under fremmedherredømmet. Han var 9 år, da sprogreskriptet af 1888 indledte sit mislykkede angreb pá det danske sprog og det danske sindelag. Det fik han selv at føle under sin første skolegang $\mathrm{i}$ firserne, hvor først en forstående lærer forestod undervisningen og blev bornenes gode ven. Han var fra Varde-egnen, en egentlig uddannelse til lærergerningen havde han ikke fáel, var ikke stiv i det tyske, og de tyske brokker, han beherskede, havde han tilegnet sig ved deltagelsen i nogle korte kursus. Nâr bornene demonslra- 
livt sang de tyske sange på deres egen måde, lagde han for det meste det døve øre til. En enkelt gang, da forvanskningen blev for påfaldende, måtte han dog bekvemme sig til at foretage en afstraffelse.

En anden lærer, der 1888 havde gjort børnene fortrolig med genforeningshåbet, blev afskediget uden pension og udvandrede til Danmark, hvor han, efter sigende ved kong Christian 9.s formidling, blev kordegn ved Frue Kirke i København. En tredie lærer havde både danske og tyske sympatier, ligeledes et eksempel på de ejendommelige forhold der dengang herskede $i$ en skole, hvor børnene alle kom fra dansksindede hjem. Sognepræsten, den for navnte pastor v. Brincken, var fra et tysk hjem i Haderslev, men báde han og hans hustru lagde ikke skjul på deres danske sindelag. Det kunne aflæses på hans pibehovede, der var forsynet med et billede af "de sidste på skansen "; men da han 1905 havde "glemt " kirkebønnen for kejseren, blev han afskediget. Den tyske lærer, der havde indberettet $»$ forsømmelsen «, fik dog en bøde, fordi han havde kaldt fru v. Brincken set satans fruentimmer i politik *.

Et ophold på Frederiksborg Højskole fik stor betydning for Peder Smidt. Sine egne evner omtaler han i denne forbindelse som under andre forhold med selvkritisk beskedenhed. Denne værdifulde egenskab, så svært han vil have ved at få den godkendt, er sikkert kommet ham til gode $i$ andre forhold. Stillet over for problemerne, tog han, hvad der fremgår af hans fremstilling, aldrig standpunkt inden efter alvorlige overvejelser. Det præger hans skildring af de politiske begivenheder, som han har fulgt med vågen og kritisk opmærksomhed. Han forłæller om sine goremål på det nationale og økonomiske område, og i forbindelse hermed om rejsningen af Spandet forsamlingshus, ligesom han giver interessante oplysninger om landbrugsfaglige og økonomiske forhold gennem årene. Inden forsamlingshuset blev rejst, blev der, fortæller han, afholdt møder i præstegården, i hvilke der ogsấ deltog tyske præster. Ja, pastor Schmidt, den senere tyske folketingsmand, var $i$ så henseende "os en god mand*, tilføjer han.

Peder Smidt gør også rede for sit politiske standpunkt og betegner sig selv som venstremand med radikal hældning. Han beundrer $\mathrm{H}$. P. Hanssen, som han giver tilslutning i alle forhold, det gælder hans holdning i Berlin, hans grænsepolitik og hans afvisning af bevægelserne. Han var modstander af den nye skoleordning for det tyske mindretal 1946, og han var med til at anbefale valget af Christmas Møller, som han beundrede.

Erindringerne viser os Peder II. Smidt som et poetisk gemyt, men også som en mand, der vidste, hvad han ville. Det vil sikkert ikke vække hans mishag, hvis nogen vil betegne ham som en egensindig natur, en egenskab, der fulgte ham i al hans færd, 
også når det gjaldt kirkelige spørgsmål, som han har interesseret sig stærkt for. Og sâ er det mest værdifulde i bogen dog vistnok skildringen af barndomshjemmet $\mathrm{i}$ de vestslesvigske omgivelser nær op til den gamle grænse, som prægede dagliglivet pá særlig máde. Han har, som han skriver i indledningen, $i$ overensstemmelse med nogle vers af Hostrup, følt det som en hjertets ret at leve livet som dansk i hjemlandet. Sasdan set kunne hans erindringer godt være blevet forsynet med undertitlen: "En samtale med mig selv".

Morten Kamphövener. 


\section{Bognyt}

Statsrådets Forhandlinger 1848-1863. VI. bind. Udgivet af Rigsarkivet ved Harald Jørgensen. (Munksgaard 1964). 688 sider.

Stot og sikkert fortsætter Rigsarkivets udgivelse af statsrädsprotokollerne, der nu med bd. VI omfatter tidsrummet $18547 / 6-185630 / 8$, d. v. s. sidste periode af ministeriet Anders Sandøe Ørsted og den overvejende del af ministeriet $P$. G. Bang. Man er dermed nảet over halvvejen med denne store publikation, hvis centrale betydning for udforskningen af årene mellem de to slesvigske krige er uomtvistelig. Også for sonderjysk historie $i$ det pågældende tidsrum er udgaven af storste betydning. Det er derfor sikkert også rigtigt, at man fortsætter som begyndt med at gengive protolollerne i fuldstændigt optryk. De udmær.kede registre sætter benytteren $i$ stand til på en let måde at finde frem til det stof, han soger.

Gig.

\section{Vejledende Arkivregistraturer XII. Rentekammeret I: Danske og norske afdelinger 1660-1848.}

Med den foreliggende registratur har Rigsarkivets besogende atter engang fäet et værdifuldt hjælpemiddel $i$ hænde, takket være hvilket han kan skaffe sig en forhåndsorientering i de arkivmasser, der findes i Rentekammerets danske og norske afdelinger. Sønderjyske historikere må ganske vist endnu savne bd. II, der vel vil omfatte Rtk.s tyske afdeling, men der vil dog også være meget at hente $i$ den foreliggende registratur, forst og fremmest $i$ de tilfalde, hvor administrationen var ens for hele monarkiet. Det gælder $i$ henhold til indledningen s. XVIII *i almindelighed for tiden for det tyske sekretariats oprettelse i 1699, samt for forst- og jagtsagerne frem til 1848 «. Men dertil kommer for den sonderjyske historiker selvfølgelig her som også med hensyn til Danske Kancelli sagerne vedr. de Kongerigske Enklaver.

Gg.

Wilh. Rust: Die Geschichte der lederverarbeitenden Handwerksberufe in der Stadt und im Amt Flensburg. Flensburg 1962. 175 sider.

I 1437 udstedtes den endnu bevarede laugs-skri for skomagerne i Flensborg, og i 1962 fejrede skomagerlauget som byens ældste sit 525-års jubilæum. I den anledning besluttede lauget at bede Wilh. Rust, 
der $\mathbf{i}$ adskillige publikationer har beskæftiget sig med Flensborgs håndværksforhold i ældre tid, om at skrive laugets historie. Resultatet er blevet en $\mathbf{i}$ det ydre ret uanselig bog, der imidlertid rummer en rigdom af stof af stor erhvervshistorisk interesse.

Fra samme år som skomagernes laugs-skrå stammer ogsă pels-bercdernes skrå, og det er da en selvfølge, at også disse beslægtede fag tages med $\mathbf{i}$ arbejdet. De to laugs-skråer bliver gennemgiet $\mathbf{i}$ hvert sil kapitel. Da imidlertid netop skomagerlauget horer til de mere ăbne laug i modsætning til de mange særdeles rigoristisk lukkede, har forfatteren også inddraget andre beslægtede fag, såsom garvere, handskemagere og sadelmagere. Bogen kommer derved ikke blot til at behandle de jubilerende skomagere, men som titlen siger, alle håndværk, der har arbejdet med læder.

Forfatteren lader sig heller ikke standse i tid af den bevarede skrii, men soger $i$ et par indledende kapitler tilbage gennem middelalderen. Han interesserer sig ikke mindst for skomagernes Sct. Jacobstlter $i$ Mariekirken og tolker - givetvis med rette - dette forhold som karakteristisk for de oprindeligt kirkeligt betonede sammenslutninger forud for dannelsen af de egentlige hindværkerlaug.

Også for tiden efter 1437 soger forfatteren ud over emnets snævrerc grænser. Parallel-forhold fra andre byer, der kan tjene til belysning af tilstandene i Flensborg, inddrages, og laugets udvikling jæunfores ofte med andre af byens laug. Vigtigere dokumenter gengives helt eller $i$ fyldige udtog, og man făr et udmærket billede af laugets indre opbygning og af forholdene mellem skomagere i byen og på landet. Flere særskilte kapitler handler om de ovrige laug indenfor læderhåndværket, og næringslovgivningen i de sidste hundrede är får sin særlige behandling.

Bogen har således i høj grad nydt godt af forfatterens store fortrolighed med den almindelige håndværkerhistorie, og den indeholder adskilligt mere, end titlen lover. Den kan derfor læeses med udbytte, ogsii hvis man beskæftiger sig med andre hindvark eller med skomagere andre steder. Det skal dog ikke skjules, at de mange sidespring kan virke lidt trættende, og da tilmed mange af bogens citater ikke forekommer helt centrale, kan den nok være noget tung at komme igennem. Det bør dog ikke afskrække de interesserede fra at suge denne bog. Dens rigdom på faktiske oplysninger og dens omhyggelige kilde- og litteraturhenvisninger giver den en værdi udover det rent lokale.

J. S.

\section{Emil Larsen: Urovækkeren Mogens Abraham Sommer med særligt henblik pd Haderslevtiden. Kobenhavn 1963, 212 sider, ill.}

Denne bog er udsendt af Instituttet for Dansk Kirkehistorie som den 17. i rækken af Kirkehistoriske Studier, og selv om den handler om en mand, som i dag vel nok er ukendt for de fleste af Sønderjyske Årbø- 
gers læsere, og livis betydning selv i samtiden vel kun var af tvivlsom værdi, er den dog værd at stifte nærmere bekendtskab med.

Sommer, der var af jødisk afstamning, blev fodt i Ribe den 4. juni 1829 godt halvandet år før forældrenes ægteskab.* Han kom i snedkerlære i Haderslev, men løb kort efter af læren, hvorefter han blev uddannet som skrædder i sin fødeby. Senere kom han til toldvæsenet i Nyborg. hvor han samtidig uddannede sig som lærer. Efter derpå en tid at have virket som hjæIpelærer i Rørvig på Sjælland, hvor han på grund af sin forsamlingsvirksomhed kom $i$ et ret skarpt modsætningsforhold til sine foresatte, blev han den 1 . november 1853 ansat som lærer ved Frederiksskolen i Haderslev.

Den nye lærer havde fra starten et godt forhold til byens præster, ligesom han stod på en god fod med den verdslige ovrighed og blev ven med "Dannevirke"s redaktør, Peter Chr. Koch. Forholdet til præsterne skulle dog ret snart kølnes, og efterhånden som Sommers virksomhed som folkeprædikant voksede $\mathrm{i}$ omfang, og hans skarpe meninger mod folkekirken og dens præster kom stærkere til udtryk, kom han i et skarpt modsætningsforhold til præsterne, navnlig til pastor Fr. Helweg, medens pastor Johannes Fibiger, som har betegnet Sommer som en ven, vedblev at være mere moderat $i$ sin omtale af ham.

Sommer drev i Haderslev en alsidig virksomhed, først og fremmest varetog han sin gerning som skolemand, men lige fra starten virkede han efter anmodning fra præsterne tillige som prædikant ved arbejdshuset, var bogagent for forskellige bogforlag og dyrkede homøopatien. 'Til det virke, forfatteren omtaler, kan endnu føjes, at Sommer i sommeren 1855 fik oprettet et bibliotek af kristelige boger, som udlåntes gratis. Da han i december 1855 aflagde regnskab for biblioteket, oplyste han blandt andet, at pastor Fibiger, der altså endnu ikke havde slået hånden af ham, havde bidraget med 4 rigsdaler, og at han $\mathrm{i}$ gaver ialt havde modtaget $\mathrm{i}$ kontanter 80 rdlr. 3 mark og 8 skilling samt en række bøger, og at der af bogbestanden på 534 bind havde været udlånt 342 .

Søren Kierkegaards skarpe angreb på den danske kirke i årene 1854-55 vakte stort postyr i Haderslev, hvor hans ivrigste forkæmpere var Peter Chr. Koch og Mogens Abraham Sommer, hvis prædikantvirksomhed med tiden tog et betydeligt omfang. Men da Sommers udfald mod præsterne blev stadig voldsommere, og hans forhold til pastor Helweg efterhanden forværredes, blev hans stilling ved skolevæsenet uudholdeligt. Han tog konsekvensen heraf og søgte sin afsked som lærer med den begrundelse, at hans helbred til dels var nedbrudt, og at han folte et indre kald til at ofre sig for en ny virksomhed. Han fortsatte sin prædikantvirksomhed i Haderslev og rundt om i landet og flyttede fra byen i 1857 .

I 1869 blev han forkæmper for socialismen, men heller ikke med socialisterne formåede han at komme $i$ godt samarbejde, så forbindelsen blev aflorudt allerede aret efter, da Sommer blev udstodt af internationale, og dog har pastor Carl Weltzer hævdet, at Sommer har været med til at præge den kirkelige indstilling, som socialdemokratiet har beholdt 
gennem mange år. Senere blev han udvandringsagent, ligesom han selv opholdt sig en årrække i Amerika.

Under sit ophold i Haderslev blev Sommer gift, men aegteskabet blev senere oplost, og han levede derefter sammen med en anden kvinde, med hvem han fik fire born, men den meget selvrelfærdige mand symes at have behandlet baide sin legitime og sin illegitime kone som mindreværdige.

Pastor Emil Larsen kommer i sin karakteristik af Sommer til den konklusion, al denne $i$ hojeste grad har overvurderet sig selv og sin betydning, men at han alligevel kom til at betyde noget lor mange mennesker, samt at han blev en urovækker, der satte folk i gang i religios henseende, og pastor Larsen slutter: Har selv Satan drevet sit spil med ham tit og mange gange - sá har Vorherre dog ogsa brugt ham. Dru kan ikke betvivles".

Forfatteren har plojet dybt i kildeme, der har varet ret omfattende og ikke altid lige let tilgængelige, men man har incltryk af, at pastor I.arsen virkelig har formäet at fat alt vesentligt med, să der her er skab! en værdifuld skildring af en mærkelig fanatiker, men samtidig er vor viden om den rorelse, der i midten af 1850 erne herskede i Haderslev. blevet foroget.

Olal" christensen.

* Sommers forældre er blevet gift i Ribe 22. januar 1831, og oplysuing('n til skifteretten $\mathrm{i}$ Alborg om, at vielsen allerede har fundet sted $\mathrm{i}$ januar 1830, hvad pastor Larsen finder lyder mere sandsynligt ‘, skyldes sikkert en fejl $\mathrm{i}$ attesten, idet attestudstederen mi have taget arstallet wverst pá kirkebogssiden og ikkt hemarket, at der laengere nede pat siden begynder et nyt ăr.

\section{Jahre Flensburger Brauereien. Emil Petersen \& Co.}

Kg. 1888-1963.

I anledning af 75 aret for oprettelsen af Flenslorg Exportbrygureri, som ved sammenslutuing med Flensborg Aktiebryggeri i 1919 blev til A/S Flensborg Bryggerier, har disse udsendt et smukt festskrift, der i billeder viser bryggerierne, som de er $\mathrm{i}$ dag, og i tekst giver den historiske baggrund. I indledningen fores byens bryggeritraditioner tilbage til Sct. Knudsgildet, og det navnes, at hyen aldrig har haft eget bryggerlaug. Størst vægt er der i fremstillingen lagl pä udviklinge'n efter det bayerske ols fremkomst i 1850 erne, idet dette ols fremtriengen sammen med den hastige industrialisering af bryggernæringen fuldstændigt forandrede vilkürene for bryggerierne. En folge af denne nye situation var grundlaeggelsen af Aktiebryggeriet i 1873 og af Exportbryggeriet 15 år sencre. Mulighederne tegnede forst godt, men efterhainden blev det klart, at de to store virksomheder ikke kunne trives i samme by, og efter forste verdenskrigs vanskelige år skete en summenshutning. I 1937 overdroges selskabet til Emil Petersen \& Co. Kg. Efter 1945 er produktionen gaiet 
stærkt fremad, og forskellige læskedrikke fabrikeres på licens. I 1959 optoges Husum bryggeriet Clausen-Fuglsang, og Flenborg bryggerierne står i dag som Sydslesvigs eneste virkelig blomstrende bryggeri med en ărlig produktion på ca. $100.000 \mathrm{hl}$. Jubilæumsskriftet giver en god baggrund for forståelsen af denne udvikling og tjener firmaet til ære.

H. H. W.

Werner Nergaard: Abenrå Gasvark 1863-1963.

Duplikeret, 28 sider.

I $1850^{\prime}$ erne begyndte man i de nordslesvigske byer at arbejde med tanken om oprettelse af gasværker, især til belysning af de mørke gader og stræder. I Haderslev oprettedes $1856-57$ et kommunalt gasværk, og samtidig anlagdes i Sønderborg et koncessioneret, privat gasværk. I Tonder var man lidt senere på færde, idet man først her i 1865 kunne tænde gasblussene.

I Ảbenrå havde fremskridtsmanden Frederik Fischer allerede fra begyndelsen af 1850 'erne i sit blad' $>$ Freia c agiteret for oprettelsen af et gasværk, og bystyret havde derefter lidt trevent måttet forhandle til forskellige sider om anlæg af denne nymodens foreteelse. Forst i 1862 besluttede bykollegierne imidlertid at lade en københavnsk entreprenør, ingeniør Howitz, opføre et gasværk for kommunens regning på den holm i Kilen, « hvor den store sten tidligere har ligget $\star$. Opførelsen fandt sted i løbet af 1863 , og byens borgere oplevede da for første gang, at alle byens gader, på grund af nedlægningen af gasrørene, lignede skyttegrave. De gamle olielamper indendørs og udendors kunne derefter forsvinde, og husmødrene kunne tilberede juleaftensnadveren 1863 ved gas. Werner Nørgaard, der meddeler dette i det letlæste, lille jubilæumsskrift på grundlag af oplysninger i byens arkiv og "Freia«, giver også en kort oversigt over gasværkets drift gennem hundrede år og om de udvidelser, som det stigende befolkningstal og ogede forbrug nødvendiggjorde. Særlig interessante er oplysningerne om begivenhederne under de store oversvømmelser i 1872, 1904 og 1931 og om besværlighederne med at holde værket i gang under de to verdenskrige. Det er en god lille beretning, som burde have været trykt og foraret gasværkets mange kunder ved jubilæet i 1963.

P. K. $I$. 


\section{Noter og nyt}

\section{Landsarkivet.}

I 1963 har Landsarkivet haft sit storste besøgstal siden oprettelsen, nemlig 2109 mod 1848 i 1962 . Til de 2109 besogende blev der ialt til brug på læsesalen fremtaget 17.632 bind og pakker. Også udlånene til andre arkiver og centralbibliotekernes læsesale har været stigende.

Landsarkivet kan på grund af pladsmangel ikke mere tage imod større afleveringer fra embederne, men der er dog stadig nogle fả meter hyldeplads til afleveringer og gaver fra private. Den betydningsfuldeste gave $i$ år er afdøde redaktør $A$. Svenssons efterladte papirer, der indeholder værdifuldt materiale til belysning af udviklingen $i$ landsdelen $i$ de sidste 50-60 år. Disse papirer er dog forelobig utilgængelige. Landsarkivet har fảet en værdifuld tilvækst til de ældre privatarkiver, idet det har modtaget farver Martin Bahnsens dagbøger og nogle af pastor Mørk Hansens erindrings- og dagbøger. Fra fhv. dommer i Lagumkloster og Tonder H. H. Stegmann og pastor emer. Chr. Andersen har Landsarkivet modtaget memoiremanuskripter, og *Frederiksklubben i Ảbenrå har deponeret sine gamle forhandlingsprotokoller. Læge Ib Ludvigsen har afleveret dele af faderens, afd. pastor C. Ludvigsens, privatarkiv, og redaktør M. Kamphövener har atter $\mathrm{i}$ år afleveret dele af sit privatarkiv. Fra Bjolderup sogn har fhv. forstelærer H. J. Bertelsen og gảrdejer Nis Mathiesen afleveret skole- og kommuneprotokoller, og fra Emmerlev sogn har fhv. førstelærer Larsen afleveret "Sognekrønike for Emmerlev sogn I-II;, der er udarbejdet af afd. degn Johannes Hansen, og som indeholder et meget værdifuldt materiale til belysning af udviklingen i sognet i 1800ârene. Endvidere har lærer Larsen afleveret Emmerlev sogns skolekommissionsprotokol, skolekrønike for Emmerlev skole og Emmerlev kommunes forhandlingsprotokol og regnskabsbog.

Sammen med Historisk Samfund for Sønderjylland arrangerede Landsarkivet 15.-24. november en mindre udstilling af gamle fotografier $i$ Lundsbjerghallerne. Under ledelse af arkivar Worsøe har Historisk Samfund for Sønderjylland sidste vinter på Landsarkivet afholdt vejledende kursus i personal- og lokalhistorisk arbejde. Også i dette efterår afholdes et personalhistorisk kursus.

Landsarkivet holdt sidste vinter forsøgsvis hver onsdag læsesalen åben fra kl. 20-22. Da der efterhånden kom godt besøg på disse aftener, har man fortsat med også $i$ år at holde læsesalen åben for besøgende hver onsdag aften. Der vil dog kun blive ekspederet kirkebøger, personregistre, skyld- og panteprotokoller samt forud reserverede sager. Også den forlængede åbningstid lordag eftermiddag (til kl. 17) har vist sig nyttig. 
De besøgende på Landsarkivets læsesal har i mange måneder været generet af støj og andre ubehageligheder fra håndværkere. Landsarkivet er opfort $i$ en udpræget sparetid 1932/33, og brandsikringen var derfor mangelfuld. Der er nu overalt i bygningen indsat solide branddøre, og etageadskillelsen er ført helt ud $\mathrm{i}$ vinduerne, hvori der også er blevet anbragt tykt trådglas. I bygningen er endvidere installeret 6 brandhydranter med tilhørende slanger og strålerør, således at en brand straks kan bekæmpes effektivt inde $i$ bygningen af personalet eller brandværnet. Tidligere havde man i magasinerne kun enkelte faste lampesteder og nogle håndlamper med lange Iøse kabler, der bestandig blev slidt itu og derfor gav anledning til kortslutninger. Nu er hele den elektriske installation blevet fornyet, og der er overalt faste lampesteder, hvilket også er en stor lettelse for det ekspederende personale. På grund af pladsmangel har man hidtil været nødt til at placere en mængde arkivalier og aviser $i$ et uafklæedt tagrum, der egentlig var beregnet til opbevaring af kasser og kassabilia. Dette tagrum er nu også blevet indrettet til et regulært magasin med nye stålreoler. Omkostningerne ved brandsikringsarbejderne $\mathrm{m}$. $\mathrm{m}$. har beløbet sig til godt $70.000 \mathrm{kr}$.

$$
\text { P. K. } 1 \text {. }
$$

\section{Haderslev Amts Museum.}

Fra Ejsbølfronten kan det nu meddeles, at denne store og vigtige udgravning er endeligt afsluttet. I sommeren 1964 blev undersøgt et mindre areal $\left(41 \mathrm{~m}^{2}\right)$ ved den sydlige side af udgravningen for at skabe sikkerhed for, at findestedet virkelig var udtomt. Det lykkedes, vi fandt næsten intet, og på udgravningsplanen ses fundet nu anbragt $i$ et udgravningsfelt med en næsten fundtom rand til alle sider. Ejsbøl er det eneste større mosefund, hvor undersøgelsen er ført til ende på dennc måde.

Efter Ejsbøl toges fat på museets næste store opgave, Olmersvold. Sammen med dr. Vilh. la Cour, som har beskæftiget sig med dette mindesmærke i mere end en menneskealder, vil denne undersøgelse blive gennemført efter en fælles plan, som i detailler udarbejdes, efterhånden som arbejdet skrider frem.

Olmersvold er et forsvarsværk, som strækker sig fra Uruehoved i nordøst til Gårdeby ved Tinglev i sydvest. Det spiller en ikke ringe rolle i den historiske litteratur, men er aldrig blevet arkæologisk undersøgt. Efter et par tidligere indledende undersegelser fra dr. la Cours side blev der $i$ år gravet to steder, ved Almstrupgårde af dr. la Cour og ved Gårdeby af Haderslev Amts Museum. Selv om vi fik et indblik i virkets konstruktion, var der også forhold, der ikke blev klarlagt, og det er nok for tidligt at udtale sig om resultaterne, før undersøgelsen ad åre er nået videre.

Udgravningssæsonen sluttede med en ældre bronzealders gravhøj ved 
Jels og en fortsættelse af undersøgelsen af den store gravplads ved Horløk.

Til sølvsamlingen er $\mathrm{i}$ årets løb indkøbt to tedåser, den ene dateret 1767, lavet af Wolf Petersen, og den anden udateret, lavet af Johan Adolf Müller.

Paul Reuter Lorenz, Punta Garda i Florida, og hans søster Anna Lisa Reuter Lorenzen, Karleby, indfandt sig i sommer på museet med en del tegninger og litografier fra deres bedstefaders, Peter Lorenzens hånd. Peter Lorenzen (1831-1916) havde $\mathrm{i}$ en årrække omkring 1860 boet $\mathrm{i}$ Iaderslev, inden han blev ,Wegebaumeister i Flensborg. Fra hans Haderslevtid stammer nogle blyantstegninger, akvareller og reproduktioner af bygninger og personer: Stiftamtet, Gammelting, Sølyst, ligesom det kendte billede af Hansborg (fra 1859) viser sig at være tegnet af Peter Lorenzen.

Tegningerne kom ved arv til Paul Reuter Lorenz i Florida og bragtes nu hjem til det stedlige museum, for hvis billedsamling de betyder en værdifuld forøgelse.

På en udstilling i Odense købte museet et maleri af Kai Trier, kirkepladsen i Lovran. Den tanke, at Kai Trier burde repræsenteres i museets kunstsamling, har museet næret længe, og det er naturligt, i betragtning af de mange år, Kai Trier har virket her, og de mange store opgaver han har løst. Men Kai Trier er stadig en kunstner i udvikling og under forandring. Forhåbentlig vil det ad åre vise sig, at det var rigtigt, at opgaven blev løst på denne udstilling, der forøvrigt fik en meget rosende kritik.

I vinteren 1963/64 holdtes på museet en arkæologisk studiekreds, hvor i labet af 14 aftener og med forevisning af over 500 lysbilleder den hjemlige oldtidshistorie blev gennemgået. Studiekredsen fik god tilslutning. Studiekredsen gentages $i$ vinter.

Ved museet er oprettet en kontorstilling. Hidtilværende revalideringskonsulent Harald Bojsen er tiltrådt som assistent fra 1. nov. 1964.

H. $N$.

\section{Åbenrå Museum 1963-64.}

I kalenderåret 1963 har besøget været stigende, og museet har været besøgt af ca. 4000 gæster (incl. udstillingsgæsterne).

Den 1. maj forlod museets daglige leder, fuldmægtig Sørensen, Åbenrå, og arkitekt Karl Adolf Flade blev konstitueret som leder, indtil hr. Sørensen, der havde fået bevilget orlov i 6 måneder, havde besluttet, om han ville vende tilbage.

Fra 1. december 1963 traf man en mere konstant ordning, idet overassistent Holger Jacobsen, der er formand for Historisk Samfunds Ảbenrå amtskreds, af magistraten blev udpeget til stillingen som den daglige leder af museet og som sekretær for museumsudvalget. 


\section{Udstillinger.}

Fra den 20. til den 23. april holdtes i museets billedsal en Kandinsky udstilling og fra den 31. januar til den 9. februar 1964 en Olivia HolmMoller udstilling. Begge var arrangeret af Abenrå Kunstforening.

Fra den 14. til den 30. marts 1964 holdt Byhistorisk Forening en udstilling, > Åbenrå i litteraturen*, en udstilling, der vakte overordentlig stor interesse.

$K ø b$.

Tre portrætbilleder malet af henholdsvis Åbenrå-maleren Jes Jessen, (Eckersbergs læremester), Åbenrå-maleren Thomas Jensen og Andreas Kjær, Øster Logum.

Et hovedvandsæg af Ảbenrå-mesteren Peter Johannsen Petersen. $1805-1873$.

Et Åbenrå-skab, Louis Seize, af mesteren Lorenz Nielsen, Ảbenrå. Modtagne gaver.

Museet har modtaget en del håndmalet porcelæn af nyere dato. Kyser og huer fra Løjt sogn fra begyndelsen af forrige ärhundrede. En stenokse, en kiste til skibstømrerværktaj, en budstikke fra Hjolderup og dokumenter til diverse ejendomme i byen.

Nyindretninger.

Museet har også i 1963 forsynet en del af udstillingslokalerne med ny gulvbelægning.

H. $J$.

\section{Museet på Sønderborg Slot.}

Besøgstallet har i året 1963-64 udvist en lille stigning med et besøgstal på godt 60.000 . Der har været en svagt faldende tendens for voksne feriegæster og en stigende for skole-elever. Entréindtægten formåede derved at tangere sidste års rekord, $45.000,00 \mathrm{kr}$. Antallet af omvisninger for skoleklasser har gennem de senere år været jæunt stigende, og det samme gælder vejledning og hjælp for lejrskolehold med sær-opgaver. I hele sommersæsonen fra maj til slutningen af september beslaglægger dette arbejde museets kustoder fuldt ud, hvorfor det har været nødvendigt at overdrage en væsentlig del af rengøringen til timelønnet personale, ligesom museet $\mathrm{i}$ ferietiden har ekstra hjælp til opsynet.

Samlingerne er også i år forøget $i$ jæun takt. Især har tekstilsamlingen nydt godt af en lang række gaver, suppleret med enkelte indkøb. Flere gode kjoler, mest fra slutningen af forrige århundrede, er skænket sammen med nogle skørter, underskørter og særke. Også huer, hatte og kap. per er sammen med et par pæne kappekurve foræret til samlingerne.

Blandt møblerne må især nævnes en sjælden egetræskiste af gotisk form med den meget sene datering 1706. En gammel plov og nogle mindre arbejdsredskaber bør nævnes blandt gaverne til landbrugsafdelingen. 
Til krigssamlingerne er skænket en række billeder, nogle uniformdele fra forste verdenskrig og forskellige udrustningsgenstande. Mindeåret for 1864 gav allerede før årsskiftet anledning til enkelte gaver, og $\mathrm{i}$ årets løb øgedes tallet, især hvad angår billeder. Men også enkelte våben og et preussisk signalhorn var blandt gaverne.

Kunstafdelingens vigtigste nyerhvervelse var to pæne store portrætter af C. W. Eckersberg, forestillende købmand A. L. Schmidt og hans hustru; billederne er enten studier til eller replikker af et stort helfigurbillede i Den hirschsprungske samling. Herefter har museet de kendteste sider af Eckersbergs kunst repræsenteret: romerske prospekter, skibsbilleder og portrætter.

Museet får også fortsat meddelelser om oldsagsfund rundt $i$ amtet. I år har det bl. a. givet anledning til prøvegravninger i nogle ildgruber fra jernalderen $i$ Adsbøl, en undersøgelse af en meget stor samling jernaldergruber på det område, hvor nu Hørup centralskole bygges, en inspektion af en mindre høj nær Gråsten og en gravning i en ompiøjet høj ved Nordborg. Sidstnævnte sted frilagdes to lange, næsten uforstyrrede rækker svære randsten fra en forlængst forsvundet langdysse, smukt beliggende på en bakketop.

Det omfattende konserveringsarbejde er fortsat. Konservator Mogens Larsen har atter behandlet middelalderlige kirkefigurer, et arbejde, der betales af en særlig bevilling gennem Statens Lokalmuseumstilsyn, men desuden er en konservering af genstande fra søfartsafdelingen påbegyndt. Museets egen konservering af umalede træsager er fortsat.

Museet har desuden fortsat registreringen af bindingsværkshuse, og stud. mag. F. Grandt-Nielsen har fotograferet en del til museets arkiv. Også revisionen af oldsagsarkivet er fortsat, idet stud. mag. Birthe Kjølbye og Søren Andersen har gennemgået og beskrevet museets stenaldersamling. Samtidig udarbejdes nye mere udforlige kartotekskort af en type, som de nordslesvigske museer er fælles om.

Også på anden måde er det nære samarbejde mellem de nordslesvigske museer fortsat. Der har været afholdt fælles møder, afskrivningsarbejdet i Nationalmuseet er fortsat og udvidet til også at omfatte I. og II. afdeling, og endelig er lysbilledsamlingen nu nảet et sådant omfang, at den er af praktisk værdi ved en række forskellige foredragsemner. På museet benyttedes den $i$ tre foredragsaftener om sonderjysk folkekultur.

Til udstillinger ved andre museer har våben, uniformsdele og billeder fra 1864 været udlånt. Desuden lånte Städtisches Museum, Flensborg, til dets store Jørgen Ovens-udstilling det store billede af den unge hertug Christian, der får tilbudt den danske krone, ligesom C. A. Jensens lille portræt af Eckersberg sendtes til Kobenhavn i forbindelse med den store udstilling "Dansk Guldalder i Stockholm. Endelig har museet som sædvanlig udlånt lokaler til forskellige udstillinger, arrangeret af Sønderborg Kunstforening og til SAMIS årlige udstilling.

J. S. 


\section{Tønder Museum.}

Takket være tilskud fra Konsul Georg Jorck og Hustru Emma Jorcks Fond lykkedes det museet at publicere sit hidtil største og smukkeste skrift, en nyudgivelse af det forlængst udsolgte Hollandske Vægfliser. I modsætning til museets tidligere skrifter udgaves det $\mathbf{i}$ forbindelse med et kobenhavnsk forlag. Det udkom december 1963 og er nær udsolgt.

Om større nyerhvervelser er der ikke tale. Betydeligst er en sukkerskål af den kendte Tander-guldsmed Paul Hansen fra 1791, et meget fornemt Louis XVI-arbejde, men desværre til en alt for høj pris. Prisudviklingen siden 1960 rammer specielt Tonder Museum bestandig hårdere, fordi netop de ting, der sætter deres præg på museet, og som udgor vort speciale, er så eftertragtede. Til gengæld medfører dette også en tilsvarende voksende interesse for museet og et dermed tiltagende bers:. Pisiget $\mathrm{i} 1964$ har passeret de 8.000 .

Magister Ebba Busch har i det forlobne år påbegyndt registrering og beskıivelse af museets samling af kniplinger og kniplingsprøver, henved 7.000 1:umre, hvortil museet har opnået hetragtelige tilskud fra Statens I.okalmuseumstilsyn. Når dette omfattende arbejde er afsluttet, vil der omsider være grundlag for planlægning af det manglende udstillingsrum for kniplingsindustrien, som paradoksalt nok ikke har eksisteret i kniplingsbyen Tonder.

En sensation fra museets virkeområde var møntfundet i Logumkloster 30. 9. 1963, som er beskrevet af Kirsten Bendixen i marts-nummeret 1964 af Nordisk numismatisk unions medlemsblad. Der afleveredes herfra 230 monter og en del krukkeskår. Monterne er fra Flensborg, Güstrow, Hamborg, Hannover, Lübeck, Lüneburg, Stettin, Stralsund, Wismar, Østfrisland og Livland o. 1379-1424.

Lovændringen af lov om de kulturhistoriske lokalmuseer af 4. marts 1964 medførte mindre okonomiske forbedringer, men nok så afgørende for de drøftelser angående de sonderjyske museers fremtidige arbejdsdeling, der i så høj grad har behersket arbejdet i museumsbestyrelsen og Nordslesvigs museumsråd, var den nye lov om statstilskud til kunstmuseer af 15. april 1964. Lovudkastet, som vi blev bekendt med pả et meget sent tidspunkt, blev ikke modtaget med absolut begejstring her $i$ landsdelen, fordi det ikke gav de muligheder for oprettelse af landsdelsmuseer for kunst, som man oprindelig havde forestillet sig. Ganske vist betyder loven en væsentlig forbedring i forhold til hidtil gældende praksis, men i modsætning til loven om de kulturhistoriske museer lægger den allerede med et lokalt tilskud på $15.000 \mathrm{kr}$. loft over statstilskuddet, som - medmindre der opnås en speciel tilslutning fra finansudvalget ikke kan udgøre mere end $25.000 \mathrm{kr}$. Ved en indgående drøftelse af landsdelsmuseumsplanen på Nordslesvigs Museumsråds made i Ảbenrå den 27. april 1964 niede man ikke til enighed, men Tonder amtsråd og byråd har - indtil nu alene i landsdelen - bevilget $15.000 \mathrm{kr}$. til drift af et kunstmuseum, og man regner med i lobet af det kommende år at 
kunne forelægge rådene et projekt til udvidelse af det nuværende museum, som kan blive grundlag for det større museumsbyggeri, der værdigt kan danne ramme om den præsentation af nordisk kunst, man onsker placeret ved grænsen. Men der er næppe tvivl om, at der vil blive stillet store krav til lokalt initiativ, hvis den smukke idé skal realiseres.

I øvrigt har samarbejdet de nordslesvigske museer imellem været fortrinligt, ligesom også forbindelserne sydpå er blevet udbyggede.

S. $S$.

\section{Restaureringen af Sønderborg Slot.}

I lobet af 1963-64 kom der oget fart i forberedelserne til den længe ventede restaurering af Sønderborg Slot. Kgl. bygningsinspektør Peter Koch havde tidligt på året afsluttet sit mere detaljerede projekt, og efter at boligministeriet havde gennemgået det, optoges på finansloven 1964-65 en forste rate på 1,5 mill. kr. Under indtryk af, at kommende restriktioner eventuelt kunne komme til at udskyde hele sagen, fremkom fra lokale myndigheder og organisationer forskellige henvendelser om at søge arbejdets igangsættelse fremskyndet. Finansudvalget aflagde derefter besøg på slottet $\mathrm{i}$ december måned, og $\mathrm{i}$ januar godkendte det, at sagen blev fremmet, endda så meget, at der kunne disponeres over en del af forste rate til materialebestillinger allerede for 1. april.

I løbet af foråret blev arbejdet derefter forberedt og tilrettelagt, og ved finansårets begyndelse begyndte restaureringsarbejdet så småt. Først i juni måned nedsatte boligministeriet imidlertid det byggeudvalg, der har den egentlige ledelse af restaureringen, og efter dettes forste møde har arbejdet kunnet tage fart.

Forste fase koncentreres om ostfløjen. Her er alt gammelt puds hugget af væggene, de mange lag gulvbrædder fjernede, lofterne stødt ned, ng de svære bjælker mellem etagerne omhyggeligt løftet ud. Efter at fløjen således er blevet rippet indvendigt, er man gået $i$ gang med fornyelsen. Der er placeret brandsikre dæk mellem etagerne, oprindelige skillevægge, der har været nedbrudte, er genopførte, og buerne over dørene er ført tilbage til deres oprindelige højde og form. En lang række nye, dårlige murreparationer er fjernet og erstattet med rekonstruktioner af de gamle forhold. Selvom østfløjen ikke skal være udstillingsfløj, men skal rumme boliger, kontorer og arkiver, afpasser man således alt det nye efter de oprindelige forhold, lader de gamle indvendige mål gælde og bygger rummene op $i$ forhold til de eksisterende, svere mure fra 1500-tallet. Der er desuden lavet et prøvevindue, der nøje gentager de rude-storrelser, profiler og karmstykker, som slottet fik i 1720'erne.

Undervejs fores et meget omhyggeligt tilsyn med arbejdet, og der udarbejdes regelmæssigt en rapport om de bygningshistoriske iagttagelser. I ostfløjen har Charles Christensens undersøgelser imidlertid været så omfattende, at de kun på mindre punkter har kunnet suppleres. Det eneste helt ukendte er vel et skydeskår til en kanon, der har siddet midt 
i den svare ostmur på 1. sal lige over porten. De gamle bageovne er blevet frilagt ved fjernelse af skillevægge fra kasernetiden, og det har vist sig, at det er muligt at restaurere dem så vidt, at de kan komme til at indgå i museets udstilling. Desuden er det tanken at inddrage kælderen syd for porten til udstilling, da de to lokaler er forbundet med en trappe, og på dette sted vise redskaber til kornets og melets behandling, bagning i ældre tid og måske også andre sider af den daglige husholdning.

Arbejdet på slottet er i fuld gang. Allerede nu træffes forberedelser til de indledende arbejder i sydfløjen, og forhåbentlig vil det blive muligt at gennemføre arbejdet kontinuerligt $i$ en fornuftig rytme de kommende år. Museet flytter imens rundt med sine samlinger, i første række mest med magasinerne, og fra østfløjen måtte hele håndværkerafdelingen placeres $i$ vest- og nordfløjen. Enkelte afdelinger vil derved i de kommende år blive stærkt overfyldte, andre steder vil rum blive inddraget til magasin, men under hele restaureringen vil museet fortsat være åbent for publikum, og dets hovedafdelinger vil til stadighed være tilgængelige.

J. $S$.

\section{Den Lüneburgske Saltoktroi.}

I SJy Arb 1963, s. 247, har en anmelder foretaget en bearbejdelse af mit talmateriale $i$ sDen Lüneburgske Saltoktroi « og tager de fremkomne summer til indtægt for, at saltoktroiens plads $\mathrm{i}$ hertugdømmernes almindelige okonomiske historie er temmelig beskeden *. Denne folgeslutning kan imidlertid ikke være rigtig. Byerne Flensborg og Abenrå havde jo oplagsfrihed for importeret salt med reeksport for oje, og saltimporten fra England kan derfor ikke - smughandelen ufortalt - komme til at stå $i$ relation til saltoktroien.

De i strømtoldregnskaberne opgivne bestemmelseshavne* siger heller intet om udlosning af salt $i$ de pågældende havne. Kun $i$ mindre grad var de slesvigske havne $i$ stand til at overtage alle de varer, som deres egne skibe bragte hjem. Resten af lasten mailte viderefragtes til Østersø-havne uden for hertugdømmerne. Derfor var der ikke megen basis for en besejling af de slesvigske havne af skibe fra andre egne, og da Flensborgs og Ảbenrås oplagsret kun gjalt for salt, tilført af egne skibe, turde spørgsmålet $\mathrm{s}$. $246>0$ den kongerigske og holstenske skibsfarts rolle $\mathrm{i}$ denne sammenhæng ( (nemlig m.h.t. salt) være overflodigt.

Med andre ord: hverken materialet i strømtoldsregistrene eller i Øresunds-toldregnskaberne lader sig benytte til en art statistik over den slesvigske saltimport.

H. V. Gregersen. 


\section{Den store egnsvandring 1964.}

Som sædvanlig havde man bestemt, at der ikke kunne indtegnes mere end 300 deltagere $i$ den store egnsvandring, som Historisk Samfund traditionen tro arrangerede i september, og som sædvanlig kom der omtrent et halvt hundrede uanmeldte interesserede, udover de 300 indtegnede. I år var problemet heldigvis ikke stort, idet turens rammer var så elastiske, at alle kunne komme med.

Mødestedet var Sønderborg Slot, og ret præcist kl. 13 var man samlet i slottets gård, hvor landsarkivar P. Kr. Iversen bød velkommen. Rektor Knud Fanø gav derefter nogle praktiske anvisninger, og så samlede museumsinspektor Jorgen Slettebo oppe på slottet så mange deltagere omkring den store plastiske gengivelse af skanserne ved Dybbøl i 1864, som kunne rummes $i$ det nyindrettede lokale. De, der ikke kunne klemme sig ind, gik glip af belæringen, men holdt sig skadeslose ved en rundgang i de tilstødende rum, hvor der jo også var nok at se på.

Med fire fulde busser $i$ spidsen og en anselig række af privatbiler (kyndige folk anslog rækken til ca. 70 biler) kørte vi derpå mod syd under museumsinspektør Hans Neumans betryggende lederskab. Gennem snoede veje $i$ den lille landsby Høruphav gik det videre mod syd til Vibæk Vandmølle, hvor ingeniør A. Jespersen fra Nationalmuseets molleudvalg fortalte om restaureringen af den gamle molle. Vi fik lejlighed til personligt at forvisse os om, at resultatet var smukt både ude og inde, og var enige om, at det eneste, den molle manglede, tilsyneladende var den drivkraft, der skulle holde molleværket i gang. Men måske er der mere vand i Vibæk om foråret. Ingeniør Jespersen, der holdt sit foredrag uden manuskript, lovede engang at samle det sagte til en artikel til Sønderjysk Månedsskrift, "når han fik tid".

På Mommark Færgegård var der dækket til kaffe, og da Ernst Cinristensen, Asserballe, havde maittet melde afbud på grund af sygdom, ledede Knud Fanø mødet. Forfatteren Martin N. Hansen læste nogle af sine egne digte op for den lydhore forsamling, hvorefter karavanen rullede mod Kegnæs kirke. Her fortalte førstelærer Georg Andreasen spredte træk fra halvøen Kegnæs' historie.

Det var en veltilrettelagt tur af overkommeligt omfang, og de enkelte punkter blev afviklet med eksemplarisk præcision. Alle deltagere fik et nummer af Sønderjysk Månedsskrift foræret, hvori man kunne læse udførligere om Kegnæs, og desuden fik man et kort over ruten, der skulle følges, med henvisninger til, hvad man kunne se fra bilen, mens man kørte.

Måske burde tidsskemaet have været lidt mindre stramt, og måske burde man til naste år overveje at bruge et transportabelt højttaleranlæg - i fri luft kan det være vanskeligt at fange foredragsholderens ord, hvis man står i yderkanten af tilhørerskaren, men bortset herfra kan man uden at overdrive betegne turen som en succes. Den var fornøjelig, afvekslende, overkommelig og billig.

ibs, 


\section{Rettelse til årbogen 1964 I}

Side 175 er følgende faldet ud efter 1. og 2. linie foroven: skridt, at Seminarieforstanderen ikke iår som ifjor marcherede

\section{Amtskredsenes arbejde}

\section{Haderslev amt.}

Vi holdt vor generalforsamling i Skrydstrup nye forsamlingshus lordag den 25. april. Vi begyndte ude ved højen på Skrydstrup mark, hvor Skrydstruppigen blev fundet. Museumsinspektør Neumann fortalte kort om de nærmere omstændigheder ved fundet og uddybede senere dette ved et lysbilledforedrag.

Bagefter tog de dygtige Skrydstrupfolk fat. Ved en aftenhøjskole for nogle år siden havde man haft den gode idé at samle på båndoptagelser - beretninger fra stedets folk om sognets ældre og nyere historie.

Lederen af dette indsamlingsarbejde, pastor Johs. Th. Nielsen, gengav nu i uddrag noget af dette. Ikke mindst beretningen om evakueringen af byen i 1944, da tyskerne anlagde flyvepladsen og tvang folk bort, var et vægtigt stykke nutidshistorie, mesterligt fortalt.

Dagen sluttede med et besøg i Skrydstrup kirke.

I stedet for sommerudflugten prøvede man i år den gode idé fra Tønder med en Historisk Søndag.

Den blev holdt den 16. august, og man havde udvalgt 6 steder, som fra kl. 14 til ca. kl. 18 kunne besøges under kyndig vejledning. Disse steder var: Årø, hvor gårdejer Brummer tog sig af de besøgende. Her var der meget stort besøg dagen igennem. Tamdruphøj med den vidunderlige udsigt over egnen. Her var gårdejer Simeon Sørensen foreviser. Museumsinspektør Neumann tog sig af det lille middelalderlige voldsted Bolet, som mange her så for første gang. I den ejendommelige Starup kirke var det pastor $\mathrm{K}$. Chr. Jensen, som fortalte. Og i Magstrups idylliske præstegårdshave viste pastor Dalberg os Kongsholm, den gamle kongebolig. Endelig havde gårdejer Iversen åbnet sin have for os, så vi så det prægtige voldsted, hvor Torning slot har stået. Havearkitekt Sv. Lindholdt viste omkring og fortalte bl. a. om den helt enestående gamle træbestand ved voldstedet.

Alt ialt blev Historisk Søndag også her i Haderslev amt en succes, som opfordrer til gentagelse. Over 400 mennesker deltog.

Indenfor amtsudvalget har man desværre måttet tage afsked med M. Toft, som er flyttet fra egnen.

T. Holm.

\section{Åbenrå amtskreds 1964.}

Den 28. april 1964 afholdtes en velbesogt generalforsamling på Ungdomshjemmet i Abenrå. Arkitekt Karl Adolf Flade og A. Wortmann, Padborg, genvalgtes til bestyrelsen. Beretning og regnskab godkendtes. 
Efter generalforsamlingen talte lærer Jes Holdt, Rugbjerg, om den sønderjyske østdialekt. "En lægmands betragtninger over vort sproge kaldte hr. Holdt sit særdeles vel underbyggede foredrag, der gjorde stor lykke hos den lydhøre forsamling. Efter kaffebordet viste lærer Høier, Løjt Kirkeby, en ganske pragtfuld farvefilm fra det skønne Løjt land, en film, der var optaget med så stor fotografisk dygtighed både $i$ valget af motiverne og rent teknisk, at tilskuerne var ganske bjergtagne. Den store deltagelse viste, at bare man finder de rette emner, kan man samle folk selv til en generalforsamling.

Søndag den 14. juni 1964 afholdtes atter sammen med Folkeligt Samfund den årlige udflugt. Den gik til Starup kirke, Arøsund, Arø og Tamdruphøj. Udflugten, somı man af hensyn til Historisk Samfunds egnsvandring havde lagt forst på sommeren, blev begunstiget af fint vejr. Pastor Urban Schroder gjorde samværet i den interessante Starup kirke til en oplevelse ved sit enestående gennemarbejdede foredrag om kirken og dens beliggenhed. Man sluttede med en salme og begav sig derefter til et veldækket kaffebord på Fargegården i Arosund. Herfra kunne de, der havde lyst, sejle til Årø, og da vejret var godt, krydsede de fleste deltagere sundet med den lille færge, der måtte sejle adskillige gange. Man kørte så til Tamdruphøj, som blev kommenteret af gårdejer Simeon Sorensen, Hajstrup, og man kunne ingen bedre have fảet dertil. Stående på højens top, nydende den vidunderligste udsigt over Lillebælt og kystlandskabet, fik man en udtømmende redegorelse for højens historie, og han fortalte også om den lige af Nationalmuseet foretagne restaurering.

Mandag den 9. november arrangerede amtskredsen en historisk aften i Varnæs, hvor overinspektør Holger Rasmussen og pastor Urban Schrøder talte. Overinspektøren viste lysbilleder fra Nationalmuseets samlinger og fortalte om livet $i$ de gamle bondergårde med særligt henblik på det sønderjyske. Desuden fortalte pastor Urhan Schrøder lokalhistorie, af Bines og Middes poesibøger og gamle madopskrifter.

H. J.

\section{Sønderborg amtgkreds.}

Ved generalforsamlingen i maj 1964 på Danebod højskole blev amtsudvalget genvalgt. Efter generalforsamlingen holdt bibliotekslektor Rerup et udmærket foredrag om A. D. Jørgensen.

Der er indtil nu (15. novbr. 1964) indgået 8 besvarelser på den udskrevne prisopgave, og bedømmelsesudvalget kan snart gå $\mathrm{i}$ gang med arbejdet.

E. C.

\section{Tonder amtskreds.}

Arsmøde og generalforsamling holdtes torsdag den 2. april på $\star$ Tønderhus e. Formanden omtalte $\mathrm{i}$ sin beretning bl. a. forsøget med Historisk 
Søndag i amtet, der havde samlet godt 500 besøgende. Såvel formandens som kassererens beretninger blev godkendt, og valgene var genvalg. I anledning af 200 året for $\mathrm{H}$. A. Brorsons død talte sognepræst, dr. theol. H. Hejselbjerg Paulsen, F jelstrup, om emnet "Salmesangen i Vestslesvig «. Modet havde samlet ca. $\mathbf{4 0}$ medlemmer.

Egnsvandringen fandt sted lordag den 23. maj med Urnehoved som samlingssted. Her fortalte fhv. gårdejer $H$. P. Jorgensen tingstedets historie og redegjorde for den nuværende festplads' tilblivelseshistorie. Selskabet, der bestod af ca. 60 personer, aflagde derefter besøg pă Olmersdiget, og ved det efterfølgende kaffebord på Kliplev kro holdt H. P. Jørgensen foredrag om Olmersdiget. Afslutningen på turen fandt sted i Kliplev kirke, hvor sognepresten, N. Møller Sørensen, var omviser.

C. $S$.

\section{Sydslesvigs amtskreds.}

I tilknytning til sidste års beretning kan vi meddele, at der i Sydslesvig indenfor Historisk Samfund har været gennemfort folgende arrangementer:

Fredag den 29. november 1963 talte museumsinspektør, forfatter Peter Seeberg, Asmindekloster, Viborg, over emnet: „En skandinavisk metropol - det middelalderlige Bergen i arkæologisk belysning *

Fredag den 31. januar 1964 talte professor, dr. phil. Kristof Glaman, Cientofte, om Ølbrygning og bryggernæring i gamle dage 4 .

Fredag den 13. marts 1964 talte professor Ljungren, Lund, Sverige, over emnet Sanct Knudsgilder før og nu«.

Amtskredsen gennemførte sin generalforsamling den 22, maj 1964 på centralbiblioteket i Flensborg. Prof. Troels Fink talte over emnet Problemer omkring et nederlag *.

Det er bleven til en god tradition, at vi hver sommer prover at gennemfore en aftenvandring. Tidligere skete det $\mathrm{i}$ Flensborg by. I år tog vi imidlertid til Slesvig. Under bibliotekar Poul Kürsteins ledelse stiftede vi bekendtskab med Det lidet kendte Lolfod«. Arrangementet har givet os mod på at fortsætte.

Der er endnu en tradition, som vi i de sidste år har veret glade for nemlig sommerens bestyrelsesmode hos lektor Th. Madsen og frue i Sønderhav. I år blev det gennemført lørdag den 20. juni, hvor vi lavede planen for vinterarbejdet $1964 / 65$.

Til hovedforeningens sommerudflugt samlede vi en busfuld medlemmer. Vi har $i$ vor amtskreds samlet vore medlemmer til en udflugt til vestkysten. Den formede sig som et besøg hos lensgreve H. Schack til Schackenborg i Møgeltønder. Det strålende septembervejr og den store gæstfrihed på Schackenborg bevirkede, at det blev en hel stor dag for os alle. Desuden fik vi lejlighed til at se Mogeltender kirke. Landsarkivar Peter $\mathrm{Kr}$. Iversen, Ảbenrå, fortalte om sin barndoms kirke, og organist Peter Jorgensen gav $i$ anledning af besøget en lille koncert. 
Turen fortsatte til Logumkloster, hvor man besogte kirken, klosteret, refugiet og bibelhøjskolen. Forstander pastor Jul. Nielsen tog imod os og fortalte på en interessant måde om arbejdet.

L. Sch.

Historisk Samfunds medlemstal 1922-1964

$\begin{array}{rrrrrr}1922 & 60 & 1937 & 637 & 1952 & 1160 \\ 1923 & 379 & 1938 & 677 & 1953 & 1180 \\ 1924 & 379 & 1939 & 691 & 1954 & 1160 \\ 1925 & 514 & 1940 & 690 & 1955 & 1160 \\ 1926 & 548 & 1941 & 696 & 1956 & 1300 \\ 1927 & 582 & 1942 & 788 & 1957 \text { ca. } & 1600 \\ 1928 & 657 & 1943 & 868 & 1958 \text { ca. } 1700 \\ 1929 & 657 & 1944 & 1035 & 1959 & 1771 \\ 1930 & 681 & 1945 & 1090 & 1960 & 1840 \\ 1931 & 701 & 1946 & 1123 & 1961 & 1886 \\ 1932 & 726 & 1947 & 1202 & 1962 & 1976 \\ 1933 & 742 & 1948 & 1225 & 1963 & 2060 \\ 1934 & 755 & 1949 \text { ca. } 1250 & 1964 & 2750 \\ 1935 & 673 & 1950 \text { ca. } 1250 & (1 . \text { dec.) } \\ 1936 & 642 & 1951 & 1140 & & \end{array}$




\title{
Årsberetning og regnskab 1963-64
}

\author{
Ved Peter Kr. Iversen og Olav Christensen.
}

Historisk Samfund for Sønderjylland holdt søndag den 31. maj 1964 årsmøde på "Folkehjem « i Ảbenrå. I anledning af de tre jubilæer: Sønderjyske Årbøger 75 år, Sønderjysk Månedsskrift 40 år og Skriftrækken 25 år, af vikledes årsmødet under særligt festlige former. Ministeren for kulturelle anliggender, Julius Bomholt, overværede mødet.

Da de ca. 250 fremmødte medlemmer havde taget plads ved de lange borde $\mathrm{i}$ »Folkehjem «s store sal, intonerede Åbenrå Vesteramts Orkester under ledelse af førstelærer P. Hansen, Hellevad, ouverturen til "Høstgildet $\ll$.

Formanden bød derefter velkommen og rettede en speciel tak til kulturministeren og forfatteren Martin N. Hansen for deres fremmøde. Formanden omtalte kort jubilæerne og udtalte, at der var noget symbolsk $\mathrm{i}$ det forhold, at det både var en festdag og en arbejdsdag, idet arbejdet for Historisk Samfund altid var blevet betragtet som en fest. "Det har været lykkeligt at se arbejdet vokse, og kontakten formidles til stadig videre kredse. Det lokalhistoriske arbejde i Sønderjylland er midt i en grotid. " Formanden takkede de to trykkerier, Hejmdals Bogtrykkeri, Åbenrå, og Th. Laursens Bogtrykkeri, Tønder, for deres fælles jubilæumsgave: en meget smuk dirigentklokke i sølv.

Forsamlingen sang derefter "Som dybest brønd ", og på formandens forslag valgtes redaktør Morten Kamphövener til dirigent. Denne konstaterede, at årsmødet var lovligt indkaldt og beslutningsdygtigt. Han gav derefter ordet til formanden, der aflagde følgende beretning:

Medlemstallet har nu passeret de 2400, og der kommer fortsat hver dag nye medlemmer. I forbindelse med vore forskellige jubilæer $\mathbf{i} a ̊ r$, bad vi alle vore medlemmer om en lille jubilæumsgave i form af et nyt medlem, og det har været glædeligt at konstatere, at mange har gjort en indsats og skaffet ikke blot et, men flere nye medlemmer. Samtidig udskrev vi en konkurrence mellem vore tillidsmænd om at skaffe flest nye 
medlemmer. Denne hvervekampagne er endnu ikke afsluttet, så vi håber på endnu mange indmeldelser. Udgivelsen af det store billedværk, som senere skal blive mere udførligt omtalt, har givet os kontakt med kredse ud over hele landet, som vi ikke tidligere har haft mulighed for at komme i forbindelse med, og også herigennem har vi fået adskillige nye medlemmer.

Vort medlemsskrift "Sønderjyske Árboger" kan i år fejre sit 75-års jubilæum, og som vore medlemmer har bemærket, udsender vi i den anledning to særligt fyldige halvbind, begge på ca. 250 sider, hvoraf De for nogle dage siden har fået det første $i$ hænde. Årbogen trykkes i år i 3000 ekspl. - det største oplag nogen historisk årbog her i landet er trykt i. Når dette har været økonomisk muligt, skyldes det udelukkende, at vi hos en lang række fonds, institutioner og virksomheder over hele lundet har mødt en enestånde velvilje og forståelse for vore ansøgninger om støtte til de særlige jubilæumspublikationer. lalt har vi modtaget $30.300 \mathrm{kr}$. i ekstraordinære tilskud, og jeg vil gerne her benytte lejligheden til at udtrykke Historisk Samfunds ærbødigste tak. En fuldstændig fortegnelse over de 29 fonds, institutioner og virksomheder, der har ydet os støtte, vil fremkomme i 2. halvbind af årbøgerne.

Medens Sønderjyske Årbøger tidligere med mellemrum har bragt over. sigter over tyske bidrag til Sønderjyllands historie, har vi denne gang af pladsmæssige hensyn udsendt Poul Kürsteins »Bibliografi over tyske bidrag 1955-1960 til Sønderjyllands historie" som et duplikeret hæfte.

For Sonderjysk Månedsskrift vil der som sædvanlig blive aflagt en særskilt beretning, men jeg vil dog gerne nævne, at også Sønderjysk Månedsskrift er inde $i$ en opgangsperiode med stigende tilgang af abonnenter. Holdertallet har nu passeret 1000, heri indbefattet de ca. 100 ekspl., der på Skoleforeningens bekostning sendes til fordeling i Sydslesvig. Jeg vil gerne takke Skoleforeningen for denne kærkomne støtte. Også Månedsskriftet har $\mathrm{i}$ år jubilæum, idet det fylder 40 år. I denne anledning og til markering af 100 -året for slaget på Dybbøl udsendtes et særligt fyldigt aprilhæfte til samtlige medlemmer af Historisk Samfund, og det viste sig at være en god reklame for tidsskriftet.

Skriftrckken tegner sig kun for en enkelt nyudgivelse i år, nemlig Tønder Seminarie-Stat, der er udarbejdet af handelsoverlærer Jens Lampe under medvirken af rektor, dr. theol. Asger Nyholm og overlærer Erik Larsen $i$ anledning af Tønder Seminariums 175-års jubilæum. Bogen forelå på seminariets jubilæumsdag d. 21. sept. 1963, og det er vort indtryk, at mange gamle dimittender fra seminariet er glade for dette nyttige opslagsværk. Med værket er et stort og meget værdifuldt personalhistorisk materiale skaffet til veje og gjort tilgængeligt - forhåbentlig vil det komme til at danne grundlaget for videregaiende undersøgelser. Vi har imidlertid ikke ligget på den lade side i skriftudvalget siden september måned - tværtimod har vi været fuldt optaget af den største opgave, Historisk Samfund hidtil har været impliceret i. Jeg tænker her på »Sønderjylland - Historisk Billedbog ", som allerede er omtalt på tidligere 
årsmøder, og som nu foreligger. De 15000 eksemplar er, som udgor første oplag, er ved at være udsolgt. Vi anslog sidste år, at budgettet for bogen ville overstige $100.000 \mathrm{kr}$., men da vi på grund af den store eftersporgsel har sat oplaget i vejret, og da omfanget også er forøget, viser det sig, at vi i stedet for kommer til at regne med et beløb pả omk ring 180-190.000 kr. for denne ene publikation. Vi har naturligvis været spændt på udfaldet, selvom vi vidste, at arbejdet var lagt $i$ de bedste hænder med museumsdirektør Jørgen Paulsen som billedredaktør, bibliotekar Poul Kürstein som tekstforfatter, Erik Ellegaard Frederiksen som tilrettelægger, Th. Laursen i Tønder som bogtrykker og Oskar Moller i Haderslev som bogbinder, men vi har med glæde konstateret, at vore forventninger til bogen er blevet indfriede, og at anmeldelserne $i$ aviserne har været meget positive. Også fra vore medlemmer har vi hørt pæne ord oin bogen.

Som nr. 31 i Skriftrækken udsendes Peder $H$. Smidts erindringsbog fra Vestslesvig Hverdag og Fest*, som vi i 25-året for udsendelsen af den forste bog i skriftrækken tilbyder vore medlemmer for $5,-\mathbf{k r}$., medens den ordinære pris bliver 10,- kr. I bogen fortæller Peder $\mathbf{H}$. Smidt om dagligliv og nationale rørelser i Vestslesvig i sidste halvdel af fremmedherredømmet, om genforeningen og om de lykkelige, men også i mange henseende vanskelige år, der fulgte. Bogen burde og skulle have været udsendt før årsmødet, men jeg har bevidst sinket færdiggørelsen, da jeg forudså, at ekspeditionen ikke ville kunne klare både udsendelsen af billedbogen og Smidts bog på samme tid. Bogen foreligger imidlertid i korrektur og vil blive udsendt om kort tid.

Under forberedelse er pastor $A$. Andersens kommenterede udgave og oversættelse af generalsuperintendent Jacob Fabricius $d$. Yngres Optegnelser fra årene 1624-42. Bogen, der vil fylde ca. 500 sider, vil blive udsendt forst på efteråret. Og endelig kan vi til jul bebude andet bind af Abenrd Bys Historie, tiden indtil 1864, idet forfatterne af de resterende afsnit har forpligtet sig til at aflevere manuskripterne i lobet af sommeren.

Ekspeditionen har i den sidste tid haft meget at gøre med at få alle bestilte eksemplarer af billedværket ud inden årsmodet. Det er dog ikke lykkedes, men i næste uge skulle alle bestilte eksemplarer gerne være ekspederede. Fhv. boghandler Harald Bo Bojesen har medvirket ved udsendelsen af de mange tusinde brstillinger.

Også $\mathbf{i}$ den forløbne vinter har der mange steder været foredragsrakker og aftenhojskoler med lokalhistorisk og personalhistorisk emne, og det er vort indtryk, at man har gjort flittigt brug af den liste over foredragsholdere, som vi hvert år lader udarbejde. Foredrayene $\mathrm{i}$ denne vinter har naturligt koncentreret sig om 1864, og interessen har været livlig. Der har også i vinter været arrangeret vejledende kursus pd Landsarkivet, det ene $\mathrm{i}$ personalhistorie, det andet i lokalhistorisk arbejde. Leder af begge kursus var arkivar Worsøe. Også i amtskredsene har der været arbejdet godt. Tre ting fortjener særligt at nævnes. I Sønderborg 
amtskreds, hvor man fra tidligere arrangementer havde lidt penge tilovers, har man udskrevet en prisopgave med emne fra lokalhistorien og stillet dels kontante præmier dels boggaver i udsigt. De præmierede bidrag vil desuden mod almindeligt honorar kunne forventes at blive offentliggjort i et af vore tidsskrifter. Den anden ting, jeg ville nævne, er, at Sydslesvig-kredsen har fortsat sidste vinters foredrag med endnu 4 foredrag af højtkvalificerede foredragsholdere som Peder Seeberg, professorerne Glaman fra Kabenhavn, Ljunggreen fra Lund og Fink. Hvis disse foredragsrækker i Flensborg kan blive en fast tradition, vil der hermed være skabt ikke blot et værdifuldt indslag $i$ det danske kulturliv syd for grænsen, men ogsả $\mathbf{i}$ det historiske oplysningsarbejde $\mathbf{i}$ hele Sønderjylland. Jeg vil gerne opfordre medlemmerne også nord for grænsen til at være opmærksom på disse foredrag. Og endelig den tredie ting, der også gerne skulle være begyndelsen til en tradition: Den Historiske Søndag, som arrangeredes af Tonder amtskreds søndag den 28. juli. Dagen formede sig på den måde, at man havde udpeget ialt 7 besøgssteder $i$ amtet, hvorimellem deltagerne selv sørgede for transport. Hvert sted gav en sagkyndig en kort vejledning. Arrangementet blev en succes, idet godt 500 deltog. Størst enkeltbesøg havde udgravningerne ved Abterp med 400 besøgende. Forhåbentlig tager en anden amtskreds tanken op i år.

Vor store fællesudflugt gik sidste år til Før med byvandring $\mathrm{i}$ Wyk og rundtur på øen. Vejret var udmærket, og turen fuldtegnet. Desværre indfandt der sig en del medlemmer, som ikke havde tilmeldt sig, hvilket forårsagede en del besvær med transporten rundt på øen og bespisnin. gen, som kun var bestilt til de forud tilmeldte. Vi håber, at vore medlemmer kan forsti̊, at det er en absolut nodvendighed at overholde tilmeldingen, idet vi ved så store udflugter ikke kan gennemføre programmet som planlagt, når det maximale tal overskrides. Vi bliver fremtidig nødt til at afvise ikke-tilmeldte ved den store udflugt.

Atter $\mathrm{i}$ år har Historisk Samfund sammen med de andre nationale foreninger deltaget i samarbejdsudvalgets oktoberkursus, der i år holdtes på Jaruplund Hojskole, og vi er ligeledes impliceret i det store stævne på Skamlingsbanken d. 12. juli i år.

Som medlem af Dansk Historisk Fallesforening har vi været præsenteret ved foreningens årsmøde $\mathrm{i}$ Alborg $\mathrm{i}$ august 1963, og vi deltager også i udsendelsen af et fælleskatalog over de historiske samfunds publikationer, som DHF agter at udsende i dette efterår. Gennem dette vil vore medlemmer få de andre historiske samfunds og museernes publikationer tilbudt til favørpriser, ligesom vi håber at komme i forbindelse med en del interesserede uden for vor nuværende medlemskreds.

Indsamlingen af traditionsstof af national-politisk art er blevet fortsat af lærer Jens Kristensen, men det bliver mere og mere klart, at en mere systematisk indsamling af traditionsstof $i$ videre forstand snarest bor iværksættes. Flere bor inddrages $i$ dette arbejde, og med henblik herpa har vi søgt kontakt med Dansk Folkemindesamling, Nationalmuseets 
etnologiske undersøgelser og det musikhistoriske institut i Århus. Vi har med repræsentanter fra disse institutioner ved et møde på Sandbjerg drøftet muligheden af at interessere studerende ved vore to seminarier for dette indsamlingsarbejde. Seminariernes historielærere, der deltog i modet, gik positivt ind for sagen, og arbejdet er nu i gang eller under forberedelse. Også i lektor Clausens indsamling af gamle viser har vi nogen grad været impliceret, og det er aftalt, at vi til vor samling kan få overspillet bånd, så langt vor okonomiske evne rækker. Også til billedsamlingen er der sket værdifulde afleveringer, bl. a. af redaktør Morten Kamphövener, fru Black Hansen, Ảbenră, og porcelænsmalerinde, fru Reese, Løjt Kirkeby. Fra de to sidste har vi fict et par gode samlinger af gamle prospektkort. I efteråret deltog Historisk Samfund med en udstilling af gamle portrætfotografier i Lundsbjerghallerne. Til disse sider af vor virksomhed har vi modtaget et tilskud fra $H$. P. Hanssens Mindefond, men det er meget begrænset, hvad vi uden faste tilskud og uden videnskabelig kvalificeret leder kan overkomme på dette felt. I forảret 1962 fremsatte Historisk Samfund et forslag om oprettelse af en lokalhistorisk samling for Sonderjylland til varetagelse af indsamling af først og fremmest traditionsstof og billedmateriale. Vi hảber meget, at denne plan om oprettelse af en Lokalhistorisk Samling med fast mandskab snart kan iværksættes, og vi håber, at de bevilgende myndigheder vil se med velvilje på vore ansogninger. Oprettelsen af den lokalhistori. ske samling må $\mathrm{i}$ den kommende tid være den vigtigste nye opgave for Historisk Samfund, og på baggrund af den voksende historiske interesse i vor landsdel foler vi, at også vi, som repræsenterer en ikke uvæsentlig side af det danske folkelige arbejde $i$ grænselandet, må kunne få andel i de bevillinger, der nu og i de kommende år vil gá til det kulturelle liv her.

Først på vor onskeseddel står da oprettelsen af faste rammer for den lokalhistoriske samling, og endvidere håber vi, at det i det kommende år vil blive muligt for os at aflonne vore redaktionssekretærer, lederen af sekretariatet, kassereren og andre af vore officialer på en mere anstændig måde, end tilfældet hidtil har været. Også forfatterhonorarerne, som vi ganske vist forhøjede for et par år siden, må vi vist se på igen.

Ser vi på beretningsåret $1963 / 64$ som helhed, kan vi vist med rette karakterisere det som et af de bedste for Historisk Samfund. Der har været livlig aktivitet på alle omrâder. Vi har oget vort medlemstal, sâledes at vi nu ubetinget er den storste af de amtşhistoriske foreninger, vi kan i 75-året for Sonderjyske Arbøger udsende den største årbog, der nogensinde er udsendt, vi har sat Sonderjysk Mảnedsskrifts abonnenttal i vejret, vi har med billedværket haft den storste salgssucces, nogen historisk forening har haft, vi har haft godt salg af nyere og ældre publikationer, og vi har haft god tilslutning til vore moder og andre arrangementer. En sådan virksomhed har kun kunnet udfoldes med stotte fra stat, kommuner og private fonds og institutioner, og vi er taknemmelige herfor. Men arbejdet kunne med al økonomisk medbør ikke 
have fảet et så stort omfang, saffremt der ikke i og uden for styrelsen fandtes dygtige og interesserede mennesker, som har villet of re mange timer af deres ofte sparsomt tilmålte fritid til at gore en indsats for at fremme det historiske arbejde $i$ vor landsdel. Disse mange gode medarbejdere, ingen nævnt, ingen glemt, takker jeg på det $h$ jerteligste.

På dirigentens forslag udsattes debatten on formandens beretning til efter regnskabsaflæggelsen. Kassereren, ekspeditionssekr. Olav Christensen, aflagde derefter det reviderede regnskab, hvoraf uddrag som sædvanlig i duplikeret form var uddelt til forsamlingen (jvf. omstående). I tilslutning til regnskabet oplyste kassereren, at man for to år siden havde passeret de $100.000 \mathrm{kr}$. i ét regnskabsår, og at man $i$ år passerede de 200.000. Medlemstallet nærmede sig de 2500 , og takket være tilskud til jubilæumsarrangementerne og billedværket var kassebeholdningen p. t. så stor som aldrig før. Dirigenten konstaterede, at revisorerne, der var tilstede, ikke havde indvendinger, hvorefter beretning og regnskab godkendtes.

Viceskoleinspektør Stenz aflagde derefter beretning og regnskab for Sønderjysk Månedsskrift. På grund af de voksende omkostninger havde Månedsskriftet trods stigende holdertal — nu 1004 abonnenter - svært ved at klare økonomien. Regnskabet balancerede med $17.238 \mathrm{kr}$., hvoraf $4000 \mathrm{kr}$. var tilskud. Chr. Stenz benyttede lejligheden til at takke Skoleforeningen, der i årets løb havde tegnet abonnement på $100 \mathrm{ekspl}$., der efter samrâd med et udvalg i Sydslesvig uddeltes gratis til interesserede syd for grænsen. Adresseret til red. Kamphövener rettedes ligeledes til Sprogforeningen tak for støtte og interesse. I anledning af 100-året for 1864 havde Månedsskriftet udsendt et særligt fyldigt aprilhæfte, der med støtte af de af formanden nævnte institutioner og virksomheder havde kunnet trykkes i 3000 ekspl. Endvidere var der i årets løb ofret mere på udstyret, hvilket nok især skyldtes fru Svenssons aktive indsats indenfor redaktionen. Chr. Stenz sluttede med en tak til holderne, styrelsen, regnskabsfører og medredaktører for godt samarbejde i årets løb. Månedsskriftets beretning og regnskab godkendtes af forsamlingen.

Til styrelsen genvalgtes derefter Olav Christensen, Troels Fink, H. V. Gregersen, Peter Kr. Iversen og Hans Worsøe.

Under punktet Eventuelt a anførte formanden som tilføjelse til beretningen for Månedsskriftet, at det netop på styrelsesmødet var vedtaget at lade fru Svensson fungere som redaktionssekretær for Månedsskriftet, således at alle henvendelser desangående fremtidig skulle rettes til hende.

Derefter tog pastor H. F. Petersen, Satrup, ordet og rettede en hjertelig tak til styrismanden" Peter $\mathrm{Kr}$. Iversen for hans store og uegennyttige indsats. Han fremhæevede formanden som et 
eksempel på det gamle ord "Vil du tænde, må du brænde", og på hans forslag udbragte forsamlingen et leve for Historisk Samfund og dets formand.

Efter formandens tak sluttede årsmødets arbejdsprogram.

Som en både festlig og gribende indledning til jubilæernes højtideligholdelse læste forfatteren Martin N. Hansen sin til lejligheden forfattede prolog, som gengives i denne årbog side 477-481.

Kulturminister Julius Bomholt talte derefter om den fælles skæbne, der skaber et folk, og nævnte, hvorledes de historiske værdier vogtedes med større inderlighed $\mathrm{i}$ et grænseland end andetsteds: "Vi må have de døde med for at kunne leve", udtalte ministeren. Ministeren omtalte videre den dobbelthed af videnskabelig omhu og personlig engagement, der var særpræget for de store sønderjyske historikere som A. D. Jørgensen, Troels Fink og Johan Hvidtfeldt. Ministeren sluttede med at udtale onsket om udbredt støtte til de videnskabelige institutioner og øget fremgang for det folkelige arbejde i landsdelen.

Efter yderligere musiceren og kaffebord talte generalkonsul, dr. phil. Troels Fink om det historiske arbejde i Sønderjylland og udtalte som jubilæumsønske, at en snarlig udvidelse af det sønderjyske landsarkiv måtte finde sted. Til slut talte rigsarkivar, dr. phil. Johan Hvidtfeldt om Historisk Samfunds virke og udtalte bl. a., at der for ham ikke bestod noget skel mellem Historisk Samfunds og Landsarkivets arbejde. Det hastede med etableringen af Lokalhistorisk Samling, og rigsarkivaren udtalte ønsket om, at denne snart ville kunne komme i gang med indsamlingen af materiale til belysning af de sidste slæglleds virke.

Landsarkivar Iversen sluttede derefter årsmødet, og man sang Martin N. Hansens "Jeg går i grønne enge" og »Der er et yndigt land «.

Jubilæumsdagen afsluttedes med middag på „Folkehjem" for styrelsen og enkelte nære medarbejdere. 


\section{Følgende enkeltpersoner, institutioner og fonds har ydet bidrag til Historisk Samfunds jubilæumsforanstaltninger:}

Arbejdernes Landsbank, Kobenhavn.

Bikuben, København.

Brede Sogns Spare- og Lånekasse, Brede.

Christmas Mollers Mindefond, Kobenhavn.

Cold Stores Fond, København.

Danmarks Nationalbank, København.

Dansk Arbejdsgiverforening, Kobenhavn.

Dansk Esso Fond, Kobenhavn.

Den Almindelige Brandforsikring for Landbygninger af 1792.

Den danske Landmandsbank, Kobenhavn.

Fabrikant Mads Clausens Fond, Havnbjerg.

Folkebanken for Als og Sundeved, Sønderborg.

Gram Bank, Gram.

Den grevelige Hielmstierne-Rosencroneske Stiftelse.

Gråsten Bank, Gråsten.

Haderslev Bys Spare- og Lånekasse, Haderslev.

Jydske Tidende, Kolding.

Konsul George Jorck og hustru Emma Jorcks Fond.

A/S Kjøbenhavns Handelsbank, København.

Kobstædernes almindelige Brandforsikring, København.

Livsforsikringsselskabet Hafnia, København.

Skibsreder A. P. Møller, København.

Den Nordslesvigske Folkebank, Abenrå.

Privatbanken i København, København.

Skærbæk Bank, Skærbæk.

Sparekassen for Haderslev Byes Omegn, Haderslev.

Sønderborg Bys Sparekasse, Sønderborg.

Tønder Landmandsbank, Tønder.

Dagbladet Vestkysten, Esbjerg.

Der er $i$ alt indkommet kr. $\mathbf{3 0 . 3 0 0 . ~}$ 
Regnskab for året 1. april 1963 til 31. marts 1964.

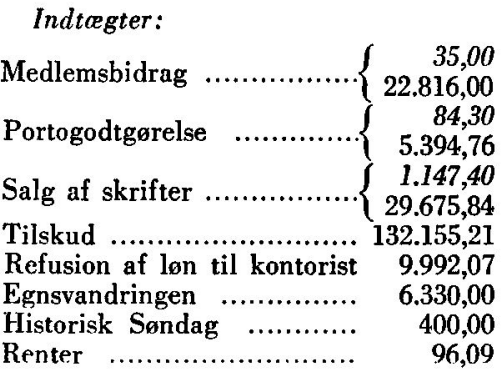

Kr. 206.859,97

DM $1.266,70$

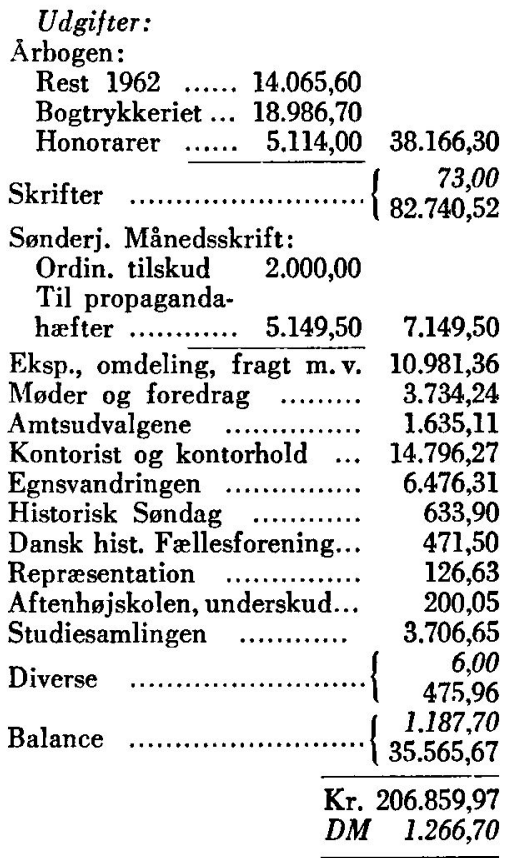

Status pr. 31. marts 1964.

Aktiver:

Beholdning ........ 36.312,62

$1.754,87 \quad D M$ ä $1,70 \quad 2.983,28$

Kontingentrestancer $\ldots . . . . .$.

Arbejdsministeriet ..............

Statstilskud 1963/64

Udestående for salg

Udlæg for påtænkte skrifter $\quad 1.866,49$

$47.714,49$

Balance
Passiver:

Oversættelse af Jacob

Fabricius $\quad \ldots . . \quad 5.000,00$

forbrugt $\ldots \ldots \ldots . \quad 2.000,00 \quad 3.000,00$

Herredsbogen, saldo ......... $1.367,25$

Tilskud til jubilæumsärg. ... $\quad 30.300,00$

Brygger J. C. Jacobsens mindelegat, tilskud til billedværket ........ 50.000,00 udb. $1963 / 64 \ldots 32.524,54 \quad 17.475,46$

H. P. Hanssens Mindefond, tilsk. til studies. $\mathbf{5 . 0 0 0 , 0 0}$ udb. $1963 / 64 \ldots \quad 3.706,65 \quad 1.293,35$

Haderslev, den 10. maj 1964.

Olav Christensen.

Undertegnede af Historisk Samfund valgte revisorer har d. d. revideret foranstående regnskab for perioden 1. april 1963 til 31. marts 1964, som er befundet 1 orden og 1 overensstemmelse med de foreliggende bilag. Kassebeholdningen pr. 31. marts er konstateret.

Haderslev, den 28. maj 1964.

Carl H. Sehrt Erik Frits. 


\section{Tillæg til medlemsfortegnelsen}

Efterfølgende supplement til den i årene 1955 til 1963 offentliggjorte medlemsfortegnelse for Historisk Samfund for Sønderjylland medtager som i de senere år i afgangslisten kun de afdøde medlemmer, hvis død er kommet til kassererens kundskab, medens tilgangslisten omfatter alle nye medlemmer i alfabetisk rækkefølge. Det bemærkes, at det er kassereren, som har ansvaret for udarbejdelsen af tillagget.

Historisk Samfund har siden årsopgørelsen i 1963 haft en nettotilgang på 627 medlemmer, hvoraf det gamle land tegner sig for over halvdelen, nemlig 327. Fremgangen fremkommer således: tilgangen af nye medlemmer er på 702, medens der foruden 21, der er afgået ved døden, er slettet 54 på grund af udmeldelse eller restance. Medlemstallet pr. 1. oktober 1964 udgør derefter 2687, der fordeler sig på Sønderjylland og det øvrige land samt udlandet som følger:

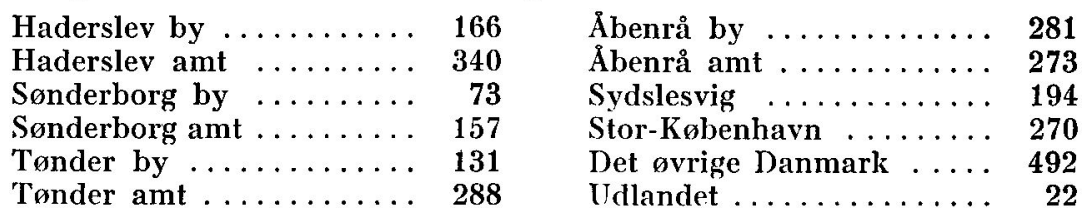

Afgang ved død

Appel, Erik, magister, Skibelund Bancke, Viggo, lærer, Tyrstrup Bladt, Jørgen gårdejer, Varnæes Grav Christensen, Anne, Mølby, Røm $\emptyset$ Eriksen, Laust N., gårdejer, Sdr. Sejerslev

Fink, Hans, gårdejer, Skovrup pr. Christiansfeld

Hansen, Jes, gårdejer, Fjelstrup Have, Ferdinand, direkt $\not r$, Ảbenrå Helkiær, Otto, viceskoleinspektør, Tonder

Jensen, P. Feddersen, Iærer, Outrup

Johansen, Jørgen, maskinmester, Ảbenrå

Linnet, H., forpagter, Møgeltønder
Madsen, Johan, maler, fhv. borgmester, Christiansfeld.

Michael, Marie, Haderslev

Nissen, Harald, civilingeni $\varnothing$ r, Klampenborg

Poulsen, M. RefsIund, rentier, Bovlund Schmidt, Ragnhild, overlærer, Vojens

Simonsen, Thomas Schultz, gårdejer, Fæsted

Sorgenfri, Jørgen, snedkermester, Haderslev

Svendsen, Th., gårdejer, Hjemsted, Skærbæk

Sørensen, S. A., snedkermester, Rødding.

\section{Tilgangsliste}

Agger, Hans, lærer, Spandet

Albertsen, Kı., læge, Moseskrænten 47, Søborg

Algreen-Petersen, J., sognepræst, Brede

Alkærsig, P., amtsskolekonsulent, Ảbenrå

Allerslev-Jensen, oberstløjtnant, Varde

Andersen, Agner Sandhøj, tilsynsførende, S $\varnothing$ nderborg

Andersen, Anne Marie, Sillehoel, L $\phi \mathbf{j t}$ Kirkeby

Andersen, Carola, sygeplejerske, Ribe
Andersen, Chr., pastor emer., Dalsgårde pr. Rinkenæs

Andersen, Christian, mælkeforhandler, Skodborg

Andersen, J. C., lærer, Nrdr. Frihavnsgade 32 II, København $\emptyset$.

Andersen, L., sognepræst, Alsted

Andersen, Lillie, husmoder, Sønderborg

Andersen, M., Jydegård, Hasle

Andersen, Poul, assurand $\emptyset r$, Helgavej 4, Odense 
Andersen, Poul A., boghandler, Helsing $\phi r$

Andersen, Stig, kaptajn, Viby J.

Andreasen, A. R., købmand, Kerteminde

Andreasen, E., apoteker, Børkop

Andreasen, Ejner, seminarieelev, Hjerting

Andresen, Jørgen, fhv. bagermester, Boviup

Andresen, Siegfred, skoleleder, Bredsted

Ankjar, Stephanie, pens. overassistent, Strandvejen $123 \mathrm{~b}$, Hellerup

Appel, C. K., direkt $\phi r$, N $\phi r$ re Sundby

Arbol, Carsten, politimester, Holbak

Arendrup, A. V., Frederiksholms Kanal 16, Kobenhavn $K$.

Arendt, Rudolph, sognepraest, Tønder

Arnvig, Sven, redaktionssekretær, Odense

Askjær, Jacob, viceforstander, Strandboulevarden 21, København $\emptyset$.

Asschenfeldt, C. St., sogneprast, Arby

Bach, Oluf, lektor, Sønderborg

Bach, Sonja, frue, Vejle

Balle, Ejler, gårdejer, Godthàb, Borød

Balle, H., forsorgsleder, Nyborg

Balslev, L., lage, Hoptrup

Barfoed, Chr., direkt $\emptyset r$, Jernbanegade 17, Odense

Bavngaard Jensen, Povl, lærer, Store V1

Bartholdy, Olga, bibliotekar, Løgumkloster refugium

Bastiansen, Ole, sognepræst, Ullerup

Beck Nielsen, 0., tandlage, Tønder

Becker, Fr. P., dekorationsmaler, Hovslund

Behn, Mats, platschef, Madángsholm, Sverige

Behnke, Th., bankdirekt $\varnothing r$, Gråsten

Bekker-Jensen, H., lektor, Kronebakken 3, Virum

Bendix, Georg, lektor, Roskilde

Bengtsson, Preben, Lundtoftsparken 47, Lyngby

Berndt, Andreas, kirketjener, Rødding

Bertelscn, Jørg., toldkontrollør, Krusa

Beuck, Theodor, Iærer, Mørkøv

Beyer, Agnete, husholdningslærerinde, Knivholtevej 16, København F.

Billum, N. Juel, pens. overlærer, Logumkloster

Bjerre, Enrico, præst, Skovlund pr. Mølby

Bjerre, Erling, bogtrykker, Skærbæk
Bjørk, E. A., dommerfuldmagtig, Haderslev

Bjørnshauge, Karen, sygeplejerske, Øster Lindet

Bladt, Jes, gărdejer, Nybøl

Bloch, Hans, husejer, Egtved

Blume Schmidt, V., uddeler, Gesten

Bodum, Peter, reklamekonsulent, L $\varnothing$ jt Kirkeby

Bolt, Kr., pensionist, Gildbro, Nordborg

Borch, Per, Borgmester Fischervej 2 XI, Valby

Borg, Arne, larer, Flensborg

Borgkvist, Kurt, Hojskolevej 4, Arhus V

Boserup, Hans, fuldmagtig, cand. polit., Granparken 167, Lyngby

Bosmann Pedersen, arkitekt, Engbakkevej 26, Charlottenlund

Boysen, Louise, børnehaveleder, Fredericia

Bracher, Joch., lærer, Holtenauer Strasse 1, Kiel

Bram, Eskild, redaktør, Haderslev

Brandenborg, Mogens, kommunelarer, Bygrænsen 12, Kastrup

Brings, Anders, lærer, Spandet

Brodersen, Edith, lærerinde, Broager

Brogaard, Per, stud. mag., Kollegium V, Arhus C.

Broholm, Frederik, afdelingsleder, Puggărdsgade $11 \mathrm{I}$, København $\mathrm{V}$.

Broue Jensen, Henrik, Paludan Müllersvej 7 , Odense

Brubn, Boye, stud. teol., Ehlers Kollegium, København $K$.

Bruhn, F. M., korrespondent, Ballerup

Bruhn, Verner, seminarieadjunkt, Esbjerg

Brønd, Evald, civilingeni $\phi r$, Bagsvard Buch, Andr., bankdirektør, Haderslev

Buch, Søren Kaper, redakt $\emptyset$, Tarm

Buch-Hansen, Leif, lærer, Hjørring

Buhl, Børge, dyrlæge, Bedsted L $\phi$

Buhr, N. Aa., forstander, Bolderslev

Burmeister, Aase, frue, Vojens

Büchert, Uffe, elev, Husby, Angel

Bylderup kommune

Bødker, Ole, lærer, Bredebro

Bøgelund, H., ingeni $\phi r$, Thorsgade 2 a, Odense

Bølling, Frands, tandlæge, Hadsten

Børsting-Andersen, J., revisor, Tønder

Carlsen, C., frue, Krogsh $\phi j 21$ I, Bagsvard

Carlsen, H. G., landsretssagf $\phi r e r$, Vestervoldgade 87, Kфbenhavn V. 
Carstensen, Vald, arkitekt, Tønder Caspersen, Lorens, forstelarer, Skrydstrup

Christensen, Chr. E., gårdefer, Asserballe

Christensen, Christian, stadsskoleinspekt $\phi r$, Ringk $\emptyset$ bing

Christensen, Ebba, socialrådgiver, Haderslev

Christensen, Erwin, faglærer, Abenrå

Christensen, Henry, lærer, Kruså

Christensen, Jørn, postassistent, Kolding

Christensen, Kai, larer, Selde, Roslev

Christensen, Kjeld, gărdejer, Tornum pr. Lintrup

Christensen, M. G., pastor, Cedar Falls, Iowa, U.S.A.

Christensen, Michael, overlærer, Jelling

Christensen, Mogens, Haderslev

Christensen, Peter, bankdirektor, Tonder

Christensen, Svend, gÅrdejer, Burkal

Christensen, Thorvald, rentier, Bredebro

Christiansen, Chr., gårdefer, A vnbøl

Christiansen, Claudius, overlærer, Flensborg

Christiansen, H., kontorchef, Vesterbrogade 198 IV, København V.

Christiansen, Henrik, hфjskoleforstander, Haslev

Christiansen, Math., fårdejer, Jejsing

Christiansen, Thyra, frk., Fensmarksgade 3 , Kobenhavn $\mathbf{N}$.

Christiansen, Aage, assistent, Haderslev

Christoffersen, Helge, stud. mag., Kollegie 5, Arhus C.

Christoffersen, Hugo, Bygdeved 27, Virum

Clausager, Søndervinge 3, Esbjerg

Clausen, Chr. R., Th. Dahlsvef 8 , Esbjerg

Clausen, Erik Schumacher, toldkontrollør, Viborg

Clausen, Mouritz, bankfuldmægtig, Odense

Clausen, Theodor, gårdejer, Lindă ved Kappel

Conradsen, Peter, maskinarbejder, Gråsten

Dahl, Leif, lærer, Bredbøl, Angel

Dandanell, H., Ingenior, Nordborg

Danielsen, Birgit, sygeplejerske, Allegade 33, Odense

Danstrup, John, redakt $\sigma$, mag. art., Ved Kæret 40, Gentofte
Danф, Gunnar, landbrugskonsulent, Struer

Dehlbæk, Henry, Sønderborg

Demant, H., toldbetjent, Padborg

Demant, J, F., overtoldbetjent, Padborg

Detlefsen, A., departementschef, Lorcksvej 4, Gentofte

Deutsche Bücherel, Abenrå

Dichmann, Kay, Nastved

Dichmann-Carlsen, Knud, overlagge, Vojle

Dinesen, Ove, proprietar, Prast $\phi$

Dirks, D., distriktsskoleinspekt $\phi r$, Flensborg

Ditlev, Lars, Iærerstuderende, Hoptrup

Dragsholt, Elly, frue, Birkeagerve] 7, Vanlose

Due, Oswald, lerer, Høve, Asnes

Duer, Thomas, ingeniфr, Nøddeh $\phi j$ 10, Holte

Dyekjaer, Erling, civilingenior, Spangsbjerg

Dyring, Sv., Iærerstuderende, Esbjerg

Dorffler, Helene, frk., Dansk Generalsekretariat, Flensborg

Bilskov, C., apoteker, Nykøbing S.

Elkjær-Larsen, Kaj, lærer, Tønder

Eldom, Frits, finansdirekt $\phi r$, Bengtasvej 2, Hellerup

Ellings $\phi e$, Grethe, lærerinde, Fredericia

EImvang, Kurt, kontorchef, Valby Langgade 207, Valby

Emborg, Elli Bjeng, Hvals $\phi$

Enemark, Johanne, frk., Dфstrup SdJ.

Enemark, Kresten, gårdejer, Døstrup Sdj.

Enemark, Svend Aage, bygmester, Døstrup Sd\}.

Eriksen, Dorothea, frue, $\boldsymbol{A}$ benrå

Fabricius, L. B., cand. Jur., Havrevej 11, Brønsh $\phi$ J

Fallesen, P., mejerist, Aggersund

Faurby-Hansen, H., lærer, Verninge

Feilberg-Jørgensen, Johs., polltimester, Silkeborg

Fink, Cacille, frk., Haderslev

Fink, Kathrine, frue, Rødding

Fink, Peter, gårdejer, Frorup

Fischer, Ame, lorer, Tonder

Flensburg Stadtarchiv

Fogd, Hans P., kommunelarer, Esbjerg

Frahm, Johan, kriminaloverbetjent, Abenrà

Frandsen, T. Bo, lærer, Hinnerup

Frederiksen, L. C., major, Haderslev

Frederlksen, Thomas, forpagter, Frederikshavn 
Frederiksen, Thorvald, kommunesekretæer, Notmark

Fridberg, Bent, Parkvej 61, Tástrup

Fris, Jorgen Kristian, montør, Haderslev

Frils, Lorenz, landinspektør, Haderslev

Frils-Andersen, W., ingenl $\phi r$, Vestergårdsgade $16 \mathrm{II}$, Arhus $\mathrm{C}$.

Frilsager, E, direkt $ø$ r, Randers

Fritzel, Ellen, sygeplejerske, Abenra

Froda, Gerda, lektor, S $\varnothing$ nderborg

Fuglsang, Anders, fhv. gårdejer, Orting

Fuglsang, Karl, murermester, Tønder

Gade, Sven Ove, fuldmagtig, Stengárdsalle 45, Lyngby

Gadebjerg, Poul Jørgen, Esbjerg

Garp, J. N., trafikkontroll $\phi r$, Tinglev

(ienster, He]ge, lage, S $\phi$ nderborg

Gjelstrup, Andr., forretningsf $\phi r e r$, Hellevad

GjesIng-Hansen, G., politifuldmangtla, Abenrå

(iottfredsen, Cathrine, økonoma, Annasvej 18 1, Hellerup

Gotthardsen, F., oberstlojtnant, Christianshavns Voldgade 8 , Kbh. $\mathrm{K}$.

Gottlieb, M., lage, Logumkloster

Gram, Axel, sogneprast, silkeborg

Grau, Christlan, Abenra

Gravesen, Agnes, overlærer, Fredertkssund

Grenaa, VIgand, kфbmand, Haslev

Grimstrup, Folke, lektor, S $\phi$ nderborg

Gubi, M. H., clvilingeniфr, Kolding

Gustenhoff, Bent, tandlage, Grindsted

Gaardhus, Niels, frimenighedsprast, Rodding

Gaardhoje, Else, frue, Nordby, Fanф

Hagedorn, Ove, Kolding

Hansen, Arne, faglærer, A benrå

Hansen, Asger, amtsvandinspekt $\phi r$, Hillerød

Hansen, Bent Stig, Nørrekær 11, Valby

Hansen, Bodil, frue, Kliplev

Hansen, Christian, kontorassistent, Abenra

Hansen, Chr. J., bankfuldmægtig, Borkop

Hansen, Claus, lærer, Rudkøbing

Hansen, Einar, lektor, Haderslev

Hansen, Eli Søvsq, politibetjent, Padborg

Hansen, Emanuel, pastor, Haderslev

Hansen, Ernst, redakt $\phi r$, Nybrovej 137, Kgs. Lynghy

Hansen, Gunhlld, kollektrice, frue, Augustenborg
Hansen, Hans Peter, grosserer, Norderallee 3, Flensborg

Hansen, Helga, sekretzr, Haderslev

Hansen, Johanie, Døstrup Sdj.

Hansen, Julius, borgmester, Ejderstedgade $8 \mathrm{II}$, Kobenhavn $\mathrm{Y}$.

Hansen, $K$. Eggers, seminarlead junkt, Hejsnger

Hansen, Knud, købmand, Skrerbak

Hansen, Laurids, aftægtsmand, Rønsdam pr. Padborg

Hansen, Lorens, forstander, lic. agro, Hojer

Hansen, Louise, frue, Rinkenæs

Hansen, Martin N., forfatter, Smedevanget 23, Odense

Hansen, O. Boye, tandlæge, Ringsted

Hansen, Peder, husejer, Fåborg

Hansen, Poul Irgens, lærer, Husum, Sydslesvig

Hansen, Rita, husmoder, Vinkel pr. Vihorg

Hansen, Sv. Aage, Risenlund, Akirkeby

Hansen, Ulla Frils, lærerinde, Ravsted

Hansen, Werner, Roskilde

Hansen, Aage, overlaerer, Abenră

Hartmann Christensen, politibetjent, Holstebro

Hartvig, Karen, assistent, Hellebak

Hattel, Erik, civilingeniør, Birkerød

Hattesen, H., kunsthandler, Flensborg

Helselberg, Christine, restauratrice, Krusă

Henriksen, K. F., tandlage, Struer

Henriksen, Niels, Skovlunde

Hernig, Vagn, købmand, Nфrrealle 23, København $\mathbf{N}$.

Hestbeck, apoteker, Terndrup

Heydenreich, C., manufakturhandler, Skarbak

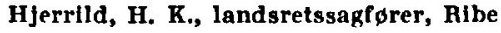

Hiort-Lorenzen, S. P., retsformand, Frederik VI's Alle 12, København F.

Hjorth, K. P., adjunkt, Fakse

Hjortlund, Alfred, pensionist, Abenrâ

Hjorskær Larsen, J., forstelærer, Døstrup Sdj.

Hoffmann, Elnor, Torveved 38, Vallensbak

Holm-Petersen, F., Troense

Holring, Axel, centralbestyrer, Stenlille

Horsbol, Gudrun, læererinde, Hellevad

Houborg, Jens Chr., Hundige skole, Greve Strand

Hundebøll Jensen, Eva, frue, Hoven Ungdomsskole pr. Tarm 
Hvalsøe, Mogens, sognepræst, Tandslet Hübschnıann, Hans Jorg., dyrlaxge, Jels Hylsebeck, toldkontroll $\emptyset r$, Arøsund

Hagstad, Arne, adjunkt, Havretoften 32, Lyngby

Høeg-Petersen, A., inspektør, Vestervang 67 , Kobenhavn, Valby

Høgsgaard, Jens L., sognepraest, Bjolderup

Hфyer, Hans, gårdejer, agronom, Steveltgård, $\emptyset$ sby

Ingernann, Lilly, prokurist, Moselund pr. Skavinge

Iversen, Arne Schmidt, lærer, Hvejsel pr. Jelling

Iversen, Nora, frk., Ustrup pr. Mastrup

Iversen, Skjold, teknisk tegner, Haderslev

Iversen, Aage, assurandor, Vejle

Jacobsen, B. T., farver, Abenră

Jacobsen, Geske Rebekke, husholdningsiprerinde, Abenrå

Jacobsen, H. C., mejeribestyrer, Kirkehorup

Jacobsen, Henning, ingeniør, Sonderborg

Jacobsen, Holg., prokurist, Sonderborg Jacobsen, Jens M., bestyrer, Skarbak

Jacobsen, Jørgen, Ullerslev

Jacobsen, Marie, frk., Abenrå

Jacobsen, Signe, lagesekretrer, Drengsted

Jacobsen, Thorkild, politimester, Hillerød

Jacobsen, Vagn Lynge, provisor, Haderslev

Jensen, B. Vestergaard, lærer, Røjlc

Jensen, Chr., bygmester, Bolderslev

Jensen, E. M., Dommerby, Hojslev st.

Jensen, Else Rahr, kommunelærerinde, Paris Boulevard 33, Hvidovre

Jensen, Henning, tandlage, Kolding

Jensen, Ib Ansgar, kommunelærer, Esbjerg

Jensen, Ib Koefod, civilingeniør, Thorvaldsensvej 2 II, København $\mathrm{V}$.

Jensen, Henry V., husejer, Ribe

Jensen, J. Jacob, rentler, Rinkenæs

Jensen, J. O., Augustenborg

Jensen, J. Vad, overlærer, Holstebro

Jensen, Jørg., gymnasieelev, Flensborg

Jensen, K. Chr., sogneprast, Starup pr. Haderslev

Jensen, Kr., rentier, Fæsted pr. Sdr. Hygum

Jensen, Lorens, bankassistent, Kruså
Jensen, P. Wrensted, tandløege, Haderslev

Jensen, T. K. A., overpakmester, Nakskov

Jensen, M. Thirup, viceskoleinspektør, Morsøvej 30, København F.

Jensen, Mogens Tving, maler, Holløse pr. Vejby

Jensen, Peter, arbejder, Blans pr. Avnbol

Jensen, Aage, lærer, Bolderslev

Jensen, Aage Bruus, overpostbud, Kors $\phi$ rgade 40 st., København $\emptyset$.

Jepsen, 0 . Lyngsted, overlage, Vejle

Jespersen, Jens, revisor, Tonder

Jessen, Frederik, Ảbenrå

Jessen, Hiske, frk., Kirkehфrup

Jessen, Iver, møller, Damgård mølle, Hovslund

Johannsen, Christine, frue, Skarbak

Johannsen, Hans, gårdejer, Engholm pr. Øster Højst

Johannsen, Kay, lærer, Tveră, Farqerne

Johannsen, Math,, Kværnholt pr. Bylderup-Bov

Johansen, Kurt, lærer, Tønder

Johansen, Otto, arbejdsmand, Stenvad, Djurs

Jordal, Bjarne, lage, Aboulevarden 82, Arhus C.

Josephsen, Johanne, fhv. forstanderinde, Ronne

Juhl, Claus, rentier, Rade pr. $\emptyset$ sby

Juhl, Elsabe, pastorinde, Kolding

Juhl, H., postmester, Tфnder

Justesen, Hans, gårdejer, Knl, Ørum, Djurs

Jorgensen, Anne, husmoder, Hjartbro

Jorgensen, Christian, lærer, Kliplev

Jorgensen, Ejner, forstander, Vesters $\phi$ gade $74 \mathrm{~V}$, Kobenhavn $\mathrm{V}$.

Jørgensen, Hakon, gymnasielærer, Flensborg

Jørgensen, Hans, ekspedient, Pjedsted

Jorgensen, Jens, cand. polit., Nordborg

Jørgensen, Jørgen, mejerist, Kliplev

Jørgensen, Jørgen Holst, redakt $\phi r$, Tonder

Jørgensen, Lis, frue, Præstevangsvej 18, Hasle

Jørgensen, Ole Juncker, repræsentant, Gerbrandsvej 12, København $S$.

Jørgensen, Sigurd, medicinalfabrikant, Varnas

Jørgensen, Svend Trøst, købmand, Qrting 
Jorgensen, Sv. Aa., advokat, Frederiksvark

Jorgensen, Sven Ole, larerstuderende, Emdrup Banke 80, Kobenhavn $\emptyset$.

Jorgensen, V. Tams, cand. mag-, Aventoft.

Kardel, A. F. W., dr. med. og dr. med. dent., Hellerup

Karstoft-Lund, Ib, cand. odont., Tonder

Keck, A. B., civilforstander, Bjerning

Kelstrup, Hans, Iarer, Sdr. Hygum

Kick-Hansen, G., sygeplejerske, Abenrå

Kielstrup, Hans, mølleejer, Sobyvad mølle pr. Hammel

Kiil, Lisbeth, adjunkt, Abenrå

Kindberg, Niels Louis, grosserer, Kastanievej 49, Odense

Kiner, Günther, repraesentant, Ligustervanget 20 II, Virum

Kjelgaard, læge, Hasserisvej 127, Alborg

Kjersgaard, Bodil, larerinde, Hoptrup

Kjargaard, Andes, landmand, Asset Løgumkloster

Kjar-Larsen, Orla, overtoldasssistent, Padborg

Klingemann, Harriet, frue, Blidahllund $1 \mathrm{II}$, Charlottenlund

Klint, Helge, oberstl $\emptyset$ jtnant, Bejledet 2 , Gentofte

Knudsen, Benedikt, cementstober, Agård

Knudsen, Else, frk., Haderslev

Knudsen, Jørgen Eli, marinekonstabel, Fredericia

Kuutz, Harald Johannes, bogholder, Abenrå

Kock, E., boghandler, Abenrå

Kock, Hanne, frue, Bag Søndermarken 17 I, København, Valby

Kock, Hans, læge, Padborg

Kock, Ingeborg, frue, Haderslev

Kock, Inger, frue, Xbenrà

Koefoed-Nielsen, E., laererstuderende, Haderslev

Koefoed-Nielsen, Stig, radioforhandler, Sønderborg

Koopmann, Hans Ferman, ungdomskonsulent, Tønning

Kornerup, Ebbe, læge, Bagsværd

Kornum, Viggo, seminarielektor, Silkeborg

Korsbrek, J. Krnuse, cellist, Sønderborg

Korsgaard, M., landbrugsleder, Renbæk pr. Arrild

Kortemann Larsen, M., larerstuderende, Skårup
Krebs Lange, Jens Chr., stud. scient,, Ryvej 1 b, Hasle, Ārhus V.

Krebs Lange, Poul, lojtnant, Fredericia

Kring, Karen, lektor, Grondalsvej 36 Y, Kobenhavn F.

Kristensen, Johan Glud, fris $\phi r$, Kongsmark

Kristlansen, Niels, arbejder, Broager

Kromann, Christian, arbejdsmand, Skxrbak

Kramer, Kjesten, frk., Tedbøl pr. Mastrup

Kramer, Marie, frue, Vedbøl pr. Mastrup

Kvarndrup, Folmer, kriminaloverbetjent, Abenrá

Kaseler, Jonna, Brande

Kørst, K. N., ekspeditionssekretzer, cand. jur., Brondbyøster Torv 28 III, Hvidovre

Kaae, Olga, forstanderinde, Løgumkloster refugium

Lammers, Karl Christian, stud. mag., Studiestræde 25 a I, Kobenhavn $K$.

Landgreen, E., kommunelarer, Barsmark

Iangdal Nielsen, N., lærer, Hjordkter

Langkilde, Arne, undervisningskonsulent, Rørkar, Jejsing

Larsen, Børge, redakt $\phi r$, A benra

Larsen, Carl, seminarielektor, Kolding

Larsen, Claus, stud. mag., Marstrandsgade 37, Kobenhavn $\emptyset$.

Larsen, Erik, overlærer, Tønder

Larsen, Gunnar, bankassistent, Skærbæk

Larsen, Henning Bussenius, stud. mag., Rendsborg

Larsen, Ingrid Lund, frk., Haderslev

Larsen, Knud Elkfar, larer, Skarbrk

Larsen, L., Hillerød

Larsen, L. P., tomrermester, Nesbyskov pr. Slagelse

Larsen, Mette Eline, frue, Tønder

Larsen, Mogens, prokurist, Fruens Bøge

Larsen, Poul, direktør, Markmandsgade 8 , Kobenhavn $\mathbf{S}$.

Larsen, S., stationsleder, Røm $\phi$

Larsen, Signe, seminarieelev, Ollerup

Lauesen, Magda, massøse, Løgumkloster

Lauridsen, Jens Chr., Iandbruggleder, Vester Terp

Lauridsen, P. C., regnskabsfører, Sommersted

Lauritzen, E. H., inspekt $\phi r$, Abenrâ

Laursen, tandlage, Holsted 
Laursen, Jørgen Wendelbo, stud. Jur., Bering pr. Hasselager

Laursen, Karen, læererinde, Vejle

Leick, Adser, viceskoleinspektør, Broager

Lempert, Gerhard, kontormedhjalper, Slesvig

Lerhard, Jenny, stud. mag., Set. Thomas Alle 5 I, København $\mathrm{V}$.

Levinsen, J. W., dommer, Gråsten

Lind, Vincent, sogneprast, Vester Aby

Linde, Niels Chr., lage, Vestre Ringgade 204 IV, Arhus C.

Lindeburg, Bent, lage, Helsinge

Lindhard, Jeanette, gymnasicelev, Vojens

Lindhardtsen, Per, stud. mag., S $\phi$ nderengen 7, København, Søborg

Lindholm, Inge, afdelingssygeplejerske, Abenrá

I.indstrøm, G., fhv. forstander, Strucksalle, Tonder

Lippert, 0., redakt $\varnothing r$, Geding

Lorensen, Georges E., Drammen, Norge

Lorenzen, Hans, bilassistent, Kristrup

Lorenzen, Magnus, lerer, Tфnder

Lorenzen, Margr., Valsbøl, Sydslesvig

Lorenzen, Signe, børnehavelaererinde, FIensborg

I.und, Birgitte, pens. Jarerinde, Sonderborg

Lund, Chr., Ollerup

Lund, Christian, gărdejer, Haderupgârd pr. Hadsund

Lund, Ellen, frue, Nalmadebro, Grásten

Lund, Kai, lage, Fredericta

Lund, Merret, stud. mag., Ved Radhuset 31 I, Vanløse

Lund Henriksen, Ove, Korinth

Lund-S $\phi$ rensen, sagf $\phi r e r$, Vestervig

Lundager Jensen, Eigil, bankfuldmagtig, Valbygardsvej $67 \mathrm{Ir}$, Valby

Lyngbye, P. B., sognepræst, Tjæreby

Lütjens, Georg, Milanovej 9 II, København S.

Lytsen, Ludolf, Den gamle gård, Daler Gsterby

Lagsmand, Karsten, stud. mag., Landsdommervej 25, København $\mathrm{NV}$.

Lærkes, Johannes, oognepræst, Egen

Løbner, Christian, larer, Nordborg

Madsen, Anna-Lisa, tandlage, Herlev

Madsen, Hilmer, ingeniør, Toftlund

Madsen, K., overvagtmester, Grasten

Madsen, Maria, formand for Dansk Sygeplejeråd, Fensmarksgade 3 IV, København $\mathbf{N}$.
Madsen, Niels Medom, distriktssekretær, Rødekro

Madsen, Svend Aage, trafikassistent, Padborg

Madsen, William, larer, Sor

Marcussen, Carl, dispach $\phi r$, Bellah $\phi j-$ vej $8 \mathrm{~V}$, Brønshoj

Marcussei, Peter, viceskoleinspekt $\phi r$, Karlslunde

Markmann, G. Reinhold, genealog, revisor, Hallingsgade 7 , Københ. $\emptyset$.

Markussen, A., filmproducent, Snogh $\phi j$

Martinsen, Viggo, politibetjent, Abenrå

Matthiesen, Matth., Lunden, Nordborg

Mauritsen, Kristian, gårdejer, Langetved

Maybom, Bent, landbrugskonsulent, Løgumkloster

Melchior, August, afdelingsleder, Blytsvej 5 II, Kфbenhavn $F$.

Melchior-Nissen, H., læge, Virum

Melvang, Frede, gărdejer, Melvanggảrd, Askov

Michelsen, Chr., gårdejer, Hơrup

Mlchelsen, E., assurand $\phi r$, Ulriksholmsvej 11, Odense

Mikkelsen, Grethe, lærerinde, Westerland, sild

Michelsen, Hans, rentier, Kildegărden, Kirkehorup

Moldt, Claus, skoleinspekt $\emptyset r$, Skjulh $\phi j$ Allé 58, Vanlose

Moltke-Leth, A., advokatfuldmrgtig, Østerbrogade 5, Kфbenhavn $\emptyset$.

Moos, Svend, gårdejer, Kollund

Mortensen, Alfred, inspekt $\phi r$, גbenrå

Mortensen, Marius, lærer, Skudstrup, Skodborg

Munk, Kirsten, lærerinde, Høruphav

Mussmann Lassen, J., guldsmed, Tinglev

Maller, Elisabeth, klasselotterikollektrfce, Sønderborg

Múller, Max, Thv. kommunekasserer, Sønderborg

Møbjerg, M., forstander, pastor, Randers

Møller, A. A., dyrlæge, Selde, Roslev

Møller, Ludvig, sparekassebogholder, Broager

Møller, Mads, gárdejer, Gejlbjerg, Frifelt

Møller, Michael, forretningsf $\phi r e r$, Christiansfeld

Møller, O. E., fuldmagtig, Solvenget 4, Kobenhavn $\emptyset$.

Mфller, Olav, bankfuldmægtig, Abenrł 
Møller, Peter, hjemmeværnskonsulent, Tonder

Møller, Rasmus, Grønland, Egernsund

Moller, Svend, ingeni $\emptyset r$, Broager

Mørk, Jørgen, fuldmagtig, Haderslev

Neumann, Einer, amtsbud, Ảbenrå

Nicolaysen, Bahne, gårdejer, Østerholun, St. Jyndevad

Nicolaysen, Gertrud, bogholderske, Abenrå

Nicolaisen, H. C., boghandler, Odder

Nielsen, Anua, toldkasserer, Esbjerg

Nielsen, Anna Marie, frue, Skibby Oed

Nielsen, Astrid, fhv. lærerinde, Hong

Nielsen, B. Skov, førstelærer, Hyllinge st.

Nielsen, Claus, overtoldassistent, Padborg

Nielsen, Erik J., kunstmaler, Vidnæsdal, Holte

Nielsen, Erik Skjold, lærer, Nyb $\phi 1$

Nielsen, Ernst Juncker, gymnasielarer, Flenshorg

Nielsen, Frands W., gărdejer, Stoustrupgárd pr. Fredericia

Nielsen, Gudrun, Virum Stationsvej 209, Virum

Nielsen, H., toldforvalter, Grảsten

Nielsen, H. C., fhv. vagtmester, Broager

Nlelsen, H. P., konsulent, Hyorslev, Ulstrup

Nielsen, Hans 0. , arbejdsmand, $\emptyset 1$ sted

Nielsen, Ingvar Andrens, tømrer, Strandvejen 723, Klampenbork

Nielsen, Peter, landmand, Brodersgărd pr. 'Tonder

Nielsen, Poul F., damefris $\phi r$, Abenrà

Nielsen, Roar, gárdejer, Olling

Nielsen, Sven, 116 Rue du Bac., Paris 7, Frankrig

Nielsen, Vagn, Haderslev

Nielsen, Vagn, korrespondent, Ndr. Frihavnsgade 26 III, København $\emptyset$.

Niemann, Ib, lærerstuderende, Hjordkær

Nierhoff, Peter, forstander, Kolding

Nissen, Cay, Irge, Poulstrup pr. Vrá

Nissen, Frede, konsulent, BylderupBov

Nissen, H., gårdejer, Stevelt, Øsby

Nissen, Hanna, assistent, Hedegård, Tinglev

Nissen, Jø̆rgen, gårdejer, Ballegárd, Blans

Nissen, Marie, frk., Haderslev

Nordbo, Knud, lektor, Roskilde
Nording, Vita, strikkeekspert, Skovmollen, Helved

Norup sogns bibliotek, pr. Otterup

Nygaard, Anders Chr., landmand, Lydersholm, Jejsing

Nykpbing F, centralbibliotek

Nørr, Erik, skoleelev, Købingsmark, Nordborg

Norregaard, Hans Chr., stud. mag., Segelckesvej 4, Kobenhavn F.

Norrelykke-Christensen, journalist, Sreby

Obeling, Laust, landmand, Astrup, Brons

Oksen, Svend, advokat, Skxrbæk

Olesen, Jakob Grandgaard, lektor, Flensborg

Olsen, Asger Svava, gymnasieoverlærer, Flensborg

Olsen, Imm., sognepræst, Nors, Thy

Ommen, Regnar, lærer, Tønder

Orbesen, J., landinspekt $\emptyset r$, Ars

Pugh, Fr., seminaieelev, Vestergårdsvej 50 II, Glostrup

Paulli, V., gartner, Egernsund

Pejtersen, J. M., laerer, Jaruplund højskole

l'eters, Theodor, skoleinspektør, Tonning

letersen, Aksel Skrydstrup, driftsassistent, Abenrå

l'etersen, Anders, Spandet

Pedersen, Anna, frk., Holballe, Over Tundslet

Petersen, Annalis Blume, frk., Flensborg

Petersen, Bothilde, overlærer, Bramminge

Petersen, C., bibliotekar, Nordborg

Petersen, Chr. Rolf, kamner, Byrum, L.aes $\phi$

Pedersen, Edvard, laerer, Steinmannsgade 2, Arhus C.

ledersen, Ellen, Arhus Plads 6 II, liøbenhavn $\emptyset$.

Petersen, Ellen, sygehjæelper, Københoved

Petersen, Em., overassistent, Tonder

Pedersen, Frederikke, husmoder, Vester Aby

Petersen, Grethe, lægesekretær, Ribc

Petersen, H. V. Dahl, tandlæge, SabyhoImsvej 36, Valby

Petersen, H. Madsen, adjunkt, Brunsnas, Broager

Petersen, Henning, konsulent, Dunkjar, Ero 
Petersen, Johanne, frue, Bylderup

Petersen, Jorgen, landmand, Tørvemosegård pr. Vester Sottrup

Petersen, Kirsten, frk., Møgelt $\emptyset n d e r$

Petersen, Magdalene, sygeplejerske, Flensborg

Petersen, Margrethe, frue, Tønder

Petersen, Marie, frue, Ravnkær, Sydslesvig

Peterseu, Marie, frk., Sønderborg

Petersen, Marie, frue, Hillerød

Petersen, Markus, landmand, Dostrup Sdj.

Petersen, Mette, frue, Abenrå

Peterseu, Niels Peter, læge, Abenrà

Petersen, Sofie, frue, Kærbølling, Rejsby

Pedersen, Svend E., adjunkt, Flensborg

Pedersen, Søren, overlaerer, Hirtshals

Pedersen, Vagn, civilingeniør, Peder Paarsvej 15, Gl. Hasseris

Petersen, Valter, landsretssagf $\emptyset \mathrm{rer}$, Toftlund

Pors, Niels Ejnar, overassistent, Ȧbenrå

Poulsen, Karen Refslund, frk., Johan Krohnsvej 6 IV, Valby

Poulsen, Aage, sognepraest, Bov

Puggărd, Holger, Vojens

Rannes, Knud, salgschef, Nørre Alle 31, Glostrup

Rasch, Erik, Abenrå

Rask, Anton, lage, Selde, Roslev

Rasmussen, Arved, portner, Asserballe

Rasmussen, Hartwig, ingeniør, Brondsted pr. Pjedsted

Rasmussen, Mads, vejformand, Dostrup Sdj.

Rasmussen, Michael, Ranum

Rasmussen, Poul Weitze, pakhusform., Dankvart Dreyersvej 21, Odense

Rasmussen, R., husejer, Skanuerup

Rathje, Paul, skoleelev, Lysabild

Ravn, Chr., Rodding

Ravn, Ejnar Andreas, radiotekniker, $\emptyset$ sby

Ravn, Sv. Aa., revisor, Abenrå

Ref shauge, K., sognepræst, Sdr. Bjart

Reuter, Ingeborg Tondering, Abenrå

Rickelt, Niels, registrator, Strandboulevarden $36 \mathrm{II}$, København $\emptyset$.

Riis, Jens, arbejdsmand, Døstrup Sdj.

Riis, Jørgen, kontorassistent, Grasten

Ringkøbing folkebogsamling

Ringsted bibliotek

Rosendahl, Johannes, forstander, Søhus

Roskilde Katedralskole
Runge- Petersen, Alfred, lierer, Abild $\mathrm{pr}^{2}$. Tonder

Rødovre kommunebibliotek

Romer, V. K., forstander, Sonderborg

Raabo, Elvind, Helsingor

Saksager, Anna, overlærer, Hjørring

Sundal, Ejvind, Ask pr. Malling

Sandberg, A., overmekaniker, Holger Drachmannsvej 15, Lyngby

Saugbjerg, Inger, stud. mag., Emiliegade 6 , Kobenhavn $V$.

Scheppelern, Otto C., stud. mag., St. Kannikestræde 9, Kobenhavn $K$.

Schlesinger, Ernst, forretningsforer, dbenrå

Schmidt, Erik, larer, Vordingborg

Schmidt, Frederik P. A., overpolitibetjent, Padborg

Schmit, Jørgen Estrup, tegner, Nyborggade 11 a, Kobenhavn $\emptyset$.

Schmidt, Karl, fangselsoverbetjent, Guldbergsgade 35 IV, Kobenhavn N.

Schmidt, Thøge Christensen, gărdejer, Dalgård, Bolderslev

Schou, Niels Kristian, larer, Thinder

Schou, Verner, laerer, Slagelse

Schou Hansen, Kaj, toldinspektor, Poppelbrekken 7, Kфbenhavn s.

Schultz, Fritz, stud. nag., Herlev

Schultz, Helmer, forstelaxrer, Vrogum

Schwarz, Helge, adjunkt, Næstved

Schytt, Otto Lawaetz, toldkontrollør, Adsb $\emptyset 1$

Schütze, Hermann, maskinmester, Haderslev

Schфler, Helge, Hăr Nedergård, Hinninge

Schonberg, Mich., overlærer, Grindsted

Schonning, Gerhard, ingeniør, $\emptyset 1 \mathrm{se-}$ nagle Strand pr. Køge

Seedorf, Henrik, adjunkt, Thisted

Serritslev-Petersen, B., audit $\varnothing r$, Haderslev

Sikkesen, Kathrine, frk., Sonderborg

Simonsen, Anna, amanuensis, cand. mag., Radmand Steins Alle $16 \mathrm{c}$, Kobenhavn $\mathrm{F}$.

Simonsen, Erik, forvalter, Stege

Simonsen, Henning, larer, Vodder

Simonsen, Knud, lærer, Sparkar

Sjøholm, Carl Christian, gymnasieelev, Nordbors

Skodsh j, Estrid, overlærer, Visby

Skovmand, Roar, professor, dr. phil., Aggersvej 4, Skodsborg

Skovsted, K., sognepræst, Skellerup pr. Ullerslev 
Skrumsager, Elisabeth, frue, Tonder

Skrydstrup, B., toldgraensedirekt $\emptyset r$, Grảsten

Skaarenborg, E., larerinde, Christiansfeld

Smed, Signe, laererinde, Lintrup

Smidt, Carsten M., overlaege, dr. med., Nastved

Stamm, K., frue, Haderslev

Steffensen, Bertel, snedker, Skærbak

Steffensen, Mathias, malkehandler, Rodding

Stenderup Jensen, Hanne, cand. mag., Sonderborg

Stensgaard, Verner, pastor, Kappel

Stidsen, Johs. E., sognepræest, Abild pr. Tonder

Stigsen, Laurits, gå rdejer, Skærbak

Storgaard, Marius, sognepsest, Dybbøl

Styck, Jens Friis, Mollerup, Visby Sdj.

Stückler, Wilhelm, maskinbygger, Flensborg

Staernose, Hans, lage, Bov

Soberg, Johannes, gårdejer, $\emptyset$. Lindet

Solbeck, Vera, frk., Tonder

Søncksen, H., direkt $\phi r$, Vejle

Sønderborg Turistforening

Sondergaard-Thomsen, Birthe, sygeplejeske, Erust Bojsensvej 1 a, Holte

Sørensen, Annegrethe, elev, Døstrup Sdj.

Sqrensen, Anne Marie, oversygeplejerske, Jagersborgvej 13, Kgs. Lyngby

Sørensen, Børge Søndergaard, laerer, Hurup, Thy

Sorensen, Chr, larer, Tonder

Sørensen, F. H., larervikar, Strandelhjorn

Sorensen, H. H., duplikeringsbureau, Stockflethsvej 38, Kobenhavn $F$.

Sorensen, Johan Klinge, laxer, Slesvig

Sorensen, Johanue Fabricius, fruc, Grasgard, Spandet

Sorensen, Kaj Skovborg, maskinurbejder, Haderslev

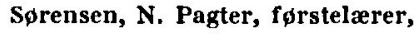
Hvidbjerg, Mors

Sorensen, P. M., undervisningsleder, Karshovedgård, Ikast

Sørensen, Richardt, pastor, Dyrehavevej 21. Arhus C.

Sørensen, Svend, pens. toldvagtmester, Padborg

Sørensen, Verner, lærerstuderende, Haderslev

Tang Koch, Istedvanget 5, Odense
'Tunge, Jef, forstander, Ronde højskole

'lappe, P., pastor, Lak, Sydslesvig

'ast, Johs. Hansen, sogneprast, Stepping

Tormansen, Anni Margrethe, Esbjerg

l'ermanen, Niels Bang, lage, Sqnderborg

Thamsen, Birgitte, stud, mag., skovvangen 11 , Charlottenlund

Theilgaard, Niels, rentier, St. Nustrup

'Thellesen, Inger Marie, reservelage, Ābenrå

Thimsen, Frede, Viuf

'Thirup, Karen, overlaerer, Sqnderlev, Vendsyssel

Thomassen, Svend Erik, skoleelev, Frederikstad, Sydslesvig

Thoms, Johannes, gartner, Rise

Thomsen, Alexander, laxge, Augustenborg

Thomsen, E., inspektør, Marienborg, Stege

Thomsen, Gregers, professor, dr. med., Indelukket 1, Hellerup

Thuesen, Mathilde, frue, Sonderborg

Thuesen, Svend E., lektor, cand. mag., synderborg

Thggersen, Ove, larer, Bajstrup

Tofte-Hansen, K., adjunkt, Dybbøl Sten

Toldam, Morten, matrikelins pekt $\emptyset r$, Fonder

Torp, L., lærer, Rodding

Tranberg, Annemette, skoleelev, Tonder

Trermoes, Mogens, advokat, Kronprinsessegade 22, København $K$.

Tving, Nicolay Jensen, maler, Holløse, Vejby

Lhre, linud Borgen, gârdejer, Uhregård pr. Tistrup

Cldall, Niels M., biblioteksstudercnde, Horsens

Ungdomsskolen i Rinkenas

Cinna, Paul, lage, Abenră

Utermohl, A., pens. larerinde, Viborg

Walter, Annemarie, lektor, Flensborg

Varde museum

Wedel Jensen, Leif, lærer, Tonder

Vejen, Marianne, overlarer, Bredebro

Wendelboe, H. P., postunester, Abenrả

Verner, Christine, pens. larerinde, Dronning Margrethesvej 25, ג rhus V.

Vestergaard, Ejnar, bibliotekar, Padborg

Videbak, Sqren, lærer, Skodborg J.

Wilhelmsen, Hans Peter, Ảbenrå

Villerslev, Kirsten, adjunkt, Gammcltoftsgade 24, København $K$. 
Wind, C., pens. forstelarer, Guderup

Vinding, Flemming, kommunelærer, Rødhrettevej 12 a, Herlev

Winkel, Esther, frue, Skovvej 77, Charlottenlund

Winther, Christian, fhv. viceskoleinspekt $\phi r$, Rodding

Winther, Niels, textllhandler, Skarbak

Wolthers, Sigv., plejeassistent, Augustenborg

Worm, Niels, Godsbunegade $16 \mathrm{II}$, Kobenhavn $\mathbf{V}$.
Wortmann, Johan Lorenz, ingeniør, Alborg

Volker, Vilhelm, arkitekt, Haslev

Yile, H., seminarieadjunkt, Siriusvej 10, Arhus C.

Ørberg, Niels Erik, forstelarer, Skellebjerg

Aagaard, H. P., gărdejer, Thorsbjerg, Over Jerstal

Augaard, Hans, overlarer, Guderup

Aaholm, Thøger, maskinmester, Shnderborg

Historisk Samfund for Sønderjylland udgiver i frit abonnement

\section{Sønderjysk Månedsskrift}

Tegn abonnement à $16 \mathrm{kr}$. årligt, og De modtager et fyldigt, månedligt hæfte med smi, letlæste artikler vedrorende historiske og kulturelle emner.

Eldre argange af Sonderjysk Manedsskrift kan koles gennem ekspeditionen, Landsarkivet, Åbenrĭ.

Prisen for et sat af de ảrgange indtil 1960, der endnu haves på lager, er kr. 25,00, enkeltårgange indtil 1956 sælges for kr. 5,00, 1957-61 kr. 10,00 pr. ârgang, 1962 ff. kr. 16,00 pr. årgang, enkelthæfter à kr. 1,00 + porto. 


\section{I serien}

\section{SKRIFTER, UDGIVNE AF HISTORISK SAMFUND FOR SØNDERJYLLAND, er udkommet:}

1. Erik Christensen: Fra min virksomhed i Tonder. Kr. 2,25. (I boghandelen kr. 4,50).

2. P. J. Refshauge: Bonden, der blev landråd. Udsolgt.

3. Tonder gennem Tiderne. Under redaktion af M. Mackeprang. Udsolgt.

4. M. H. Nielsen: Fra slesvigsk fattigvæesens fortid. Kr. 4,50 $(9,00)$.

5. Troels Fink og Johan Hvidtfeldt: Vejledning i studiet af Sønderjyllands historie. Udsolgt.

6. Navneregister til H. P. Hanssens værker. Udg. af Johan Hvidtfeldt. Kr. $2,00(4,00)$.

7. Aktstykker vedrorende Kreditanstalt Vogelgesangs tilblivelse. Udsolgt.

8. Peter Kr. Iversen: Vejledning for sønderjyske lokalhistorikere. Kr. $2,00(4,00)$. Udsolgt.

9. Johan Hvidtfeldt: Slægtshistoriske studier i Sønderjylland. Uds.

10. Nordslesvigs åndelige genforening med Danmark, Red. af Cl. Eskildsen, J. Hvidtfeldt og Peter Kr. Iversen. Kr. 6,00 (12,00).

11. Olav Christensen: Bibliografi over sonderjysk slægtstavlelitteratur, 2. udg. m. tillæg: Manuskripter vedr. sønderjysk personalhistorie $i$ Landsarkivet i Abenrå ved Peter $\mathrm{Kr}$. Iversen. Indb. kr. 7,50 (15,00).

12. Nordslesvig efter genforeningen. 7 radioforedrag. Udsolgt.

13. Thorvald Petersen: Fra Als til Tonder. Udsolgt.

14. N. Black Hansen: Ảbenrå annaler, 1524, 1584-1694. Kr. 4,00 (8,00).

15. Peter Kr. Iversen: Kniplingskræmmer Jens Wulffs dagbog. Uds.

16. A. Svensson: Redaktør J. Jessen, Flensborg Avis. I uds., II kr. $10,00(20,00)$, III kr. $15,00(30,00)$.

17. H. V. Gregersen: Niels Heldvad. En biografi. Kr. 8,00 (16,00).

18. Erland Maller og Johan Hvidtfeldt: Kaptajn Hans Bruhns Erindringer. Udsolgt.

19. Asger Nyholm: Nationale og religiøse brydninger $i$ Tonder på sprogreskripternes tid. Indb. kr. 12,00 $(24,00)$.

20. Knud Kretzschmer: Den sønderjydske Fond. Kr. 8,00 (16,00).

21. H. V. Gregersen: Gotiske skriftprover fra sonderjyske arkivalier. Kr. $8,00(16,00)$.

22. Aage Bonde og Johan Hvidtfeldt: Borgmestre, rådmænd, byfogder og byskrivere i Flensborg 1550-1848. Indb. kr. 6,00 (12,00).

23. G. Japsen: Den nationale udvikling i Abenrả 1800-1850.

Indb. kr. 15,00 $(30,00)$. 
24. Sigurd Schoubye: Guldsmedehåndværket i Tønder og på Tønderegnen 1550-1900. Udsolgt.

25. Ảbenrå Bys Historie I. Under redaktion af Johan Hvidtfeldt og Peter Kr. Iversen. Indb. kr. 16,50 $(33,00)$. Bd. II udkommer 1965.

26. Harald Jørgensen: To Ungdomsvenner. En brevveksling mellem H. P. Hanssen og H. V. Clausen. Indb. kr. 15,00 (30,00).

27. H. Hejselbjerg Paulsen: Sonderjysk Psalmesang 1717-1740. Indb. kr. 22,00 $(44,00)$.

28. H. V. Gregersen: Den Lüneburgske Saltoktroi. Et bidrag til salthandelens historie i hertugdommet Slesvig. Indb. kr. 17,00 $(34,00)$.

29. Johan Hvidtfeldt: Kampen om ophævelsen af livegenskabet i Slesvig og Holsten 1795-1805. Indb. kr. 25,00 (50,00).

30. Tonder Seminarie-Stat 1788-1963. Indb. kr. 25,00 (50,00). Udarb. af Jens Lampe under medvirken af A. Nyholm og Erik Larsen.

31. Peder H. Smidt: Hverdag og Fest - Vestslesvigske Minder. Udsolgt.

32. Jacob Fabricius d. Yngres Optegnelser. Tekst, oversættelse og noter v. pastor emer. A. Andersen. Indb. kr. 30,00 (60,00).

SONDERJYLLAND - HISTORISK BILLEDBOG

v. Jørgen Paulsen og Poul Kürstein. 256 s. Indb. kr. 15,00 (30,00).

Nyt oplag vil foreligge ca. 1. marts.

I Historisk Samfund for Sønderjyllands serie af små, populære levnedsskildringer er udkommet:

Marie Boesen: Agnes Smidt fra Lundsmark. Træk af en livshistorie. Udsolgt.

Hans Hansen: Fra tidlig vår til efterår. I sønderjysk landbrugs tjeneste. Kr. 5,00 (10,00).

Morten Kamphövener: Skrumsager. En sønderjysk fører.

Kr. 5,00 $(10,00)$.

Johan Meyer: Det gamle Froslev. Indb. kr. $5,00(10,00)$.

Th. Kaufmann: Minder og tanker. Erindringer fra grænselandet. Indb. 5,50 (11,00).

Frederik Høyberg: Gennem $80 \AA$ r. Indb. kr. $5,50(11,00)$.

De to serier redigeres af et udvalg bestående af generalkonsul, dr. phil. Troels Fink, Flensborg, seminarielektor H. V. Gregersen, Haderslev, rigsarkivar, dr. phil. Johan Hvidtfeldt, København, landsarkivar Peter Kr. Iversen, Åbenrå, og forstander Hans Lund, Tanderupgård. Manuskripter og henvendelser til redaktionen iøvrigt sendes til redaktionssekretæren, seminarielektor H. V. Gregersen, Dronning Alexandrinesvej 2, Haderslev. 
har følgende styrelse:

Formand: landsarkivar Peter Kr. Iversen, Abenrå

Kasserer: ekspeditionssekretær Olav Christensen, Haderslev

Sekretær: viceskoleinspektør Chr. Stenz, ābenrả

Amtsudvalgsformænd :

Gdr. Ernst Christensen, Asserballe pastor Tage Holm, Vojens overassistent Holger Jacobsen, Abenrà pastor H. F. Petersen, Satrup, Angel gdr. Cornelius Schmidt, Døstrup

Styrelsesmedlemmer i $\emptyset \mathrm{vrigt}$ :

Viceskoleinspekt $\emptyset \mathrm{r}$ Werner Christiansen, Tonder

rektor Knud Fanø, Flensborg

generalkonsul, professor, dr, phil.

Troels Fink, Flensborg

seminarielektor H. V. Gregersen, Haderslev provst emer., dr, theol. Jens Holdt, Askov rigsarkivar, dr. phil. Johan Hvidtfeldt, København

fhv. højskoleforstander Hans Lund, Tanderupgård pr. Ribe

seminarielektor, dr. phil. Sig. Schoubye, Tonder

cand. polit. fru Inger Bjørn Svensson,

Haderslev

apoteker, dr. pharm. Hans-Iver Toft, Tønder arkivar Hans $H$. Wors $\emptyset$, Ảbenrå

Formanden, kassereren og sekretæeren danner forretningsudvalget

Sekretariat og ekspedition :

Landsarkivet, Åbenrå, (arkivar Hans $H$. Worsøe)

tlf. $(046) 22704$. Giro 116642

Redaktionsadresser :

Sфnderjyske Årbøger: Knud Fanф, box D, Gråsten Bank, Kruså

Sønderjysk Månedsskrift :

Fru Inger Bjørn Svensson,

H. P. Hanssensvej 9, Haderslev

Skriftrækken: H. V. Gregersen, Dronning Alexandrinesvej 2, Haderslev

Kassererens adresse:

Olav Christensen, Christiansfeldvej 30, Haderslev, giro : $\mathbf{4 2 6 8 2}$

Sønderjyske Årbøger er Historisk Samfunds medlemsskrift. Medlemskontingent er p. t. 11,50 kr. + porto $\mathrm{m}$. v.

Indmeldelser modtages af selkretariatet, af alle styrelsesmedlemmer og de lokale tillidsmænd

Sønderjyske Årbøger og Skrifterne er 1 kommission hos

Danske Boghandleres Kommissionsanstalt, Nyropsgade 19, Købehavn $V$. 
HEJM DALS BOGTRYKKERI, AABENRAA . 


\section{Historisk Samfund for Sønderjylland}

holder

\section{jubilæumsårsmøde}

søndag den 31. maj kl. 14,00, på Folkehjem, Åbenrå.

\section{Dagsorden:}

1. Beretning.

2. Regnskab.

3. Beretning og regnskab for Sønderjysk Månedsskrift.

4. Valg (efter tur afgår: Olav Christensen, Troels Fink, $H$. V. Gregersen, Peter Kr. Iversen og Hans H. Worsae).

5. Eventuelt.

\section{Fælles kaffebord}

\section{Prolog ved Martin N. Hansen}

Korte taler af:

Kulturminister Julius Bombolt, generalkonsul, dr. phil. Troels Fink, rigsarkivar, dr. phil. Johan Hvidtfeldt og forstander Hans Lund.

Musikalsk underholdning ved Åbenrå Vesteramts Amatørorkester, dirigent: førstelærer P. Hansen, Hellevad.

$\mathrm{Vi}$ opfordrer vore medlemmer til at møde talrigt op og være med til at gøre dagen festlig. 